\title{
Pengaruh Kompensasi, Pelatihan Kerja dan Kepuasan Kerja Terhadap Kinerja Karyawan
}

\author{
Citra Andriani \\ Program Studi Manajemen UM. Bengkulu \\ citraandriani@yahoo.com
}

\begin{abstract}
This study entitled the effect of Compensation, Job Training and Job Satisfaction on Marketing Employee Performance at PT. Agung Toyota Bengkulu. The formulation of the problem in this study was whether the effect of Compensation, Job Training and Job Satisfaction on Marketing Employee Performance at PT. Agung Toyota Bengkulu. The purpose of this study was to determine whether the influence of Compensation, Job Training and Job Satisfaction on Marketing Employee Performance at PT. Agung Toyota Bengkulu.

This research was conducted on marketing employees of PT. Agung Toyota Bengkulu. While the time of this study was conducted for 11 days, namely on 18 January to 28 January 2020. The population of this study were employees at PT. Agung Toyota Bengkulu, while the sample of this research is marketing employees of PT. Agung Toyota Bengkulu, amounting to 97 people. This means that the sample material uses quantitative methods.

With research test data analysis techniques, the results of the study can be concluded that the respondents' perceptions about Compensation $\left(\mathrm{X}_{1}\right)$, Job Training $\left(\mathrm{X}_{2}\right)$ and Job Satisfaction $\left(\mathrm{X}_{3}\right)$ affect the Performance of Marketing Employees (Y) with the results of multiple linear regression obtained the following equation: $\mathrm{Y}=1.734+0.378\left(\mathrm{X}_{1}\right)+$ $0.570\left(\mathrm{X}_{2}\right)+0.328\left(\mathrm{X}_{3}\right)$ and the coefficient of determination of $\mathrm{R} 2=0.802$ or approximately (802\%) through hypothesis testing simultaneously (simultaneously) and individually (partial) in this study by using the $\mathrm{f}$ test and $\mathrm{t}$ test, Compensation $\left(\mathrm{X}_{1}\right)$, Job Training $\left(\mathrm{X}_{2}\right)$ and Job Satisfaction $\left(\mathrm{X}_{3}\right),=0.000$, it means that values $<0.05$ show together and have significant influence.
\end{abstract}

Keywords: Compensation, Training, Job Satisfaction, Employee Performance 


\section{BAB I}

\section{PENDAHULUAN}

\subsection{Latar Belakang}

Dalam menghadapi persaingan bisnis di era globalisasi, banyak perusahaan melakukan pengembangan sumber daya manusia dalam upaya untuk mencapai tujuannya. Perusahaan sangat tergantung pada baik dan buruknya sumber daya manusia yang dimilikinya, oleh karena itu pelaksanaan suatu pengembangan sumber daya manusia dimaksudkan agar karyawan dapat meningkatkan kinerjanya sehingga mereka dapat lebih produktif dalam melaksanakan pekerjaannya. Sehubungan dengan hal tersebut maka wajarlah apabila permasalahan yang menyangkut tentang pengembangan sumber daya manusia mendapat penanganan dan pemikiran yang lebih serius.

Sumber daya manusia merupakan faktor penting penentu kesuksesan perusahaan dalam mencapai tujuannya, karena berhasil atau tidaknya perusahaan dalam mencapai tujuan sangat tergantung pada kemampuan SDM atau karyawannya dalam menjalankan tugas-tugas yang diberikan. Kemampuan karyawan dalam menjalankan tugas-tugasnya dapat dilihat melalui kinerjanya, sehingga kinerja karyawan menjadi hal yang sangat penting bagi keberhasilan perusahaan. Kinerja karyawan adalah keluaran yang dihasilkan oleh fungsi-fungsi atau dimensi pekerjaan atau profesi yang dilaksanakan oleh sumber daya manusia atau pegawai dalam waktu tertentu (Wirawan, 2013, p. 732).

Pengembangan ilmu pengetahuan dan teknologi yang sangat pesat membawa dampak positif terhadap arti pentingnya manajemen sumber daya manusia dalam melaksanakan aktivitas perusahaan tentang pemakaian tenaga kerja yang mempunyai peranan penting. Salah satu aspek pengelolaan sumber daya manusia adalah melalui 
pelatihan. Dengan adanya pelatihan pada perusahaan maka kegiatan perusahaandapat dilaksanakan secara efektif dan efisien (Herlina Hariawati, 2009:120).

Kinerja menurut Ruky yang dikutip oleh Mangkunegara (2010:6) adalah suatu bentuk usaha kegiatan atau program yang diprakarsai dan dilaksanakan oleh pimpinan organisasi atau perusahaan untuk mengarahkan dan mengendalikan prestasi karyawan, Amstrong mengatakan bahwa manajemen kinerja adalah cara untuk memberikan pendekatan yang lebih terintegrasi dan berkelanjutan dari pada yang diberikan oleh pendekatan terdahulu yang terisolasi dan terkadang menggunakan skema penilaian kinerja yang tidak memadai.

Kinerja yang tinggi dapat tercapai dalam suatu perusahaan apabila karyawan tersebut diberikan program pelatihan dan kompensasi terhadap karyawannya. Upaya yang dilakukan dalam meningkatkan kinerja karyawan yaitu dengan pendidikan dan latihan, pemindahan pegawai keposisi yang tepat, dan promosi jabatan, dalam rangka peningkatan kualitas tenaga kerja yang diharapkan dapat memperbaiki pekerjaan yang sekarang maupun yang akan datang, serta mempengaruhi sikap atau menambah kecakapan.

Kompensasi dibedakan ke dalam dua kelompok, yaitu kompensasi dalam bentuk financial dan kompensasi dalam bentuk non financial. Menurut Henry (2013:89), kompensasi financial merupakan kompensasi yang bersifat langsung yang diterima oleh karyawan yang terdiri dari gaji, tunjangan, dan insentif. Menurut Sutrisno (2009(, kompensasi non financial adalah kompensasi yang tidak dapat dirasakan oleh karyawan. Kompensasi non financial diberikan oleh perusahaan sebagai usaha dari perusahaan untuk meningkatkan kesejahteraan karyawannya. Kompenasasi non financial bisa berupa pujian dari pimpinan, fasilitas yang diberikan perusahaan, lingkungan kerja perusahaan. 
Pemberian kompensasi sangat penting bagi karyawan, karena besar kecilnya kompensasi merupakan ukuran terhadap kinerja karyawan, maka apabila sistem kompensasi yang diberikan perusahaan cukup adil bagi karyawan, hal tersebut akan mendorong karyawan untuk lebih baik dalam melakukan pekerjaannya dan lebih bertanggung jawab atas masing-masing tugas yang diberikan perusahaan. Kompensasi juga dapat diartikan sebagai terhadap setiap bentuk penghargaan yang diberikan kepada karyawan sebagai balas jasa atas kontribusi yang mereka berikan kepada organisasi.PT. Agung Toyota Bengkulu memberikan kompensasi dengan bentuk pemberian insentif kepada karyawan, untuk meningkatkan kinerja karyawan.

Pelatihan kerja adalah pelatihan mempersiapkan orang untuk melakukan pekerjaan mereka sekarang mereka sekarang dan pengembangan mempersiapkan pegawai yang membutuhkan pengetahuan, keterampilan dan sikap ( Davis dan Werther, 2010: 164).

Hasibuan (2009) menyatakan bahwa kepuasan kerja adalah sikap emosional yang menyenangkan dan mencintai pekerjaannya. Sikap ini dicerminkan oleh moral kerja, kedisiplinan dan prestasi kerja.

Dalam rangka untuk mengetahui pengaruh pelatihan terhadap kinerja karyawan, peneliti memilih PT. Agung Toyota Bengkulu sebagai obyek penelitian. Pemilihan PT. Agung Toyota Bengkulu sebagai obyek penelitian didasari oleh beberapa pertimbangan. Pertama, PT. Agung Toyota Bengkulu merupakan suatu perusahaan yang bergerak dibidang penjualan dan servis kendaraan merek Toyota sehingga dibutuhkan suatu pelatihan khususnya pada bagian teknisi untuk dapat meningkatkan kinerja. Kedua, PT. Agung Toyota Bengkulu secara rutin selalu menyelenggarakan kegiatan program pelatihan dengan tujuan untuk menyiapkan tenaga kerja yang terampil pada pekerjaannya sehingga, pada akhirnya nanti para tenaga kerja diharapkan dapat ningkatkan kinerjanya. 
Untuk lebih mengetahui gambaran tingkat kinerja karyawan pada PT. Agung Toyota Bengkulu, peneliti mengadakan observasi dalam bentuk wawancara dengan salah satu karyawan marketing pada hari/tanggal sabtu, 16 November 2019 Pukul 09.31 WIB bahwa target pencapaian penjualan mobil pada perusahaan PT Agung Toyota Bengkulu untuk bulan agustus, september dan nopember 2019 belum tercapai. Hal ini diduga karena belum optimalnya kinerja karyawan bidang marketing. Semakin tingginya pencapaian target yang ditetapkan perusahaan maka semakin tinggi pula kinerja penjualan. Belum optimalnya capaian target tersebut diduga karena faktor kompensasi, pelatihan dan kepuasan kerja karyawan bidang marketing itu sendiri.

Berdasarkan permasalahan di atas, maka peneliti tertarik melakukan sebuah penelitian dengan judul " Pengaruh Kompensasi, Pelatihan Kerja dan Kepuasan Kerja Terhadap Kinerja Karyawan Marketing pada PT Agung Toyota Bengkulu"

\subsection{Identifikasi Masalah}

Berdasarkan latar belakang yang telah diuraikan di atas, dapat teridentifikasi masalah sebagai berikut:

1. Karyawan akan mendapatkan insentif dan bonus jika target yang ditetapkan tercapai sebaliknya jika karyawan tidak mencapai target yang ditetapkan maka karyawan tidak akan mendapatkan insentif dan bonus.

2. Pelatihan kerja pada PT. Agung Toyota karyawan pada saat pelatihan kerja masih banyak tidak memahami materi yang di sampaikan oleh si pemateri.

3. Banyaknya karyawan yang keluar masuk pada PT. Agung Toyota Bengkulu

\subsection{Batasan Masalah}


Dalam penelitian, penting untuk menetapkan batasan masalah agar tidak terjadi pembahasan yang terlalu luas dan juga karena adanya keterbatasan penulis, penelitian ini dibatasi pada hal-hal yang menjadi tujuan penelitian yaitu :

a. Ruang lingkup objek penelitian ini dikhususkan kepada karyawan marketing Agung Toyota Bengkulu.

b. Objek yang diteliti adalah pengaruh kompensasi, pelatihan kerja dan kepuasan kerja terhadap kinerja karyawan marketing pada PT Agung Toyota Bengkulu

\subsection{Rumusan Masalah}

Berdasarkan latar belakang diatas, maka dirumuskan masalah sebagai berikut:

1. Apakah Kompensasi berpengaruh terhadap kinerja karyawan marketing di PT Agung Toyota Bengkulu?

2. Apakah Pelatihan Kerja berpengaruh terhadap kinerja karyawan marketing di PT Agung Toyota Bengkulu?

3. Apakah Kepuasan Kerja berpengaruh terhadap kinerja karyawan marketing di PT Agung Toyota Bengkulu?

4. Apakah Kompensasi, pelatihan kerja dan kepuasan kerja terhadap kinerja karyawan marketing di PT Toyota Agung Bengkulu?

\subsection{Tujuan Penelitian}

\subsubsection{Tujuan Umum}

Tujuan penelitian ini adalah untuk mengetahui Pengaruh Kompensasi, Pelatihan Kerja dan Kepuasan Kerja Terhadap Kinerja Karyawan Marketing pada PT. Agung Toyota Bengkulu. 


\subsubsection{Tujuan Khusus}

a. Untuk mengetahui pengaruh Kompensasi terhadap kinerja karywan marketing pada PT. Agung Toyota?

b. Untuk mengetahui pengaruh pelatihan kerja terhadap kinerja karyawan marketing pada PT. Agung Toyota Bengkulu?

c. Untuk mengetahuipengaruh kepuasan kerja terhadap kinerja karywan marketing pada PT. Agung Toyota Bengkulu?

d. Untuk mengetahui pengaruh Kompensasi, Pelatihan Kerja dan Kepuasan Kerja terhadap kinerja karyawan marketing pada PT. Agung Toyota Bengkulu?

\subsection{Manfaat Penelitian}

Adapun manfaat penelitian ini adalah :

1. Bagi PT. Agung Toyota Bengkulu diharapkan penelitian ini data dijadikan bahan masukan atau dasar untuk lebih memperhatikan kompensasi, pelatihan kerja, dan kepuasan kerja dalam upaya untuk terus mempertahankan kinerja karyawan.

2. Bagi peneliti, memberikan wawasan dan pengetahuan yang berharga sehingga dapat mengetahui masalah-masalah yang berkaitan dalam bidang pengelolaan Sumber Daya Manusia. 


\section{BAB II}

\section{STUDI PUSTAKA}

\subsection{Deskripsi Konseptual}

\subsubsection{Kinerja Karyawan}

Kinerja karyawan adalah hasil kerja secara kualitas dan kuantitas yang dicapai oleh sesorang karyawan dalam melaksanakan tugasnya sesuai dengan tanggung jawab yang diberikan kepadanya (Mangkunegara, 2013, Onsardi, O., 2019).

Kinerja menurut Ruky yang dikutip oleh Mangkunegara (2010:6) adalah suatu bentuk usaha kegiatan atau program yang diprakarsai dan dilaksanakan oleh pimpinan organisasi atau perusahaan untuk mengarahkan dan mengendalikan prestasi karyawan, Amstrong mengatakan bahwa manajemen kinerja adalah cara untuk memberikan pendekatan yang lebih terintegrasi dan berkelanjutan dari pada yang diberikan oleh pendekatan terdahulu yang terisolasi dan terkadang menggunakan skema penilaian kinerja yang tidak memadai.

Menurut sedermayanti (2011, p.260), kinerja merupakan hasil kerja seorang karyawan, sebuah proses manajemen secara keseluruhan, dimana hasil kerja seorang tersebut harus dapat ditunjukkan buktinya secara konkrit dan dapat diukur. Kinerja menurut Torang (2013, p.74) adalah kuantitas dan kualitas hasil kerja individu atau sekelompok di dalam perusahaan dalam melaksanakan tugas pokok dan fungsi yang berpedoman pada norma, standar operasional prosedur, criteria dan ukuran yang telah ditetapkan oleh perusahaan. Lebih lanjut bahwa kinerja itu adalah unjuk kerja karyawan pada suatu perusahaan yang merupakan pencerminan loyalitas mereka dimana mereka bekerja (Asmawi, M., 2017, Anjani, R., 2019, Onsardi, O., 2018) 
Berdasarkan teori-teori diatas dapat disimpulkan bahwa Kinerja adalah hasil atau tingkat keberhasilan seseorang secara keseleruhan selama periode tertentu di dalam melaksanakan tugas seperti target atau sasaran, standar hasil kerja yang telah disepakati bersama.

\subsubsection{Faktor-faktor yang mempengaruhi Kinerja}

Menurut Handoko (2010;98), faktor-faktor yang mempengaruhi kinerja adalah:

a. Keterampilan atau Pengalaman

Orang yang mempunyai pendidikan yang rendah, jelas mempunyai keterampilan yang kurang, begitu juga orang yang sudah berpendidikan agak tinggi masih tetap mempunyai produktivitas yang rendah. Oleh sebab itu, maka perlu adanya keterpaduan antara keterampilan dengan pengalaman kerja. Tenaga kerja yang masih muda atau baru mulai mengikuti karier, biasanya bekerja agak kurang pengalaman, hal ini dapat diatasi dengan cara mengikuti pelatihan kerja di luar atau pada tempat kerja untuk meningkatkan keterampilan.

b. Faktor Pendidikan

Perusahaan perindustrian biasanya direkrut dari orang-orang yang kurang mempunyai pendidikan yang tinggi, perusahaan hanya membutuhkan kesehatan fisik yang kuat untuk bekerja. Pendidikan yang kurang dari pekerja akan menyebabkan penurunan produktivitas kerja.

c. Umur

seseorang tenaga kerja agaknya dapat dijadikan sebgai tolak ukur dari produktivitas, akan tetapi hal tersebut tidak selalu begitu. Tetapi pengajaran karier seseorang selalu diimbangi dengan jumlah umur, dimana semakin bertambah lama orang itu bekerja, maka produktivitas dari orang tersebut akan meningkat. 
d. Sarana Penunjang

Tingkat kemampuan pimpinan untuk menumbuhkan motivasi kerjasama yang baik antara para pekerja serta mengadakan pembagian kerja yang jelas antara semua karyawan sangat berpengaruh terhadap tingkat produktivitas. Disamping itu dapat juga berupa penerapan teknologi sarana produksi yang cukup canggih, hal ini akan menyebabkan tugas atau kerja dari karyawan tersebut berkurang.

e. Faktor Semangat dan Kegairahan Kerja

Dengan adanya dorongan moril terhadap para pekerja akan meningkatkan produktivitas kerja. Dorongan moril tersebut dapat berupa memberikan semangat dan kegairahan kerja kepada para pekerja. Seperti yang dikemukakan oleh pakar manajemen, seraangat dan kegairahan kerja merupakan problematik yang harus mendapat perhatian yang serius.

f. Faktor Motivasi

Faktor motivasi adalah suatu dorongan dalam diri karyawan untuk melakukan suatu kegiatan atau tugas dengan sebaik-baiknya agar mampu mencapai kinerja dengan predikat yang bagus.

\subsubsection{Tujuan Penilaian Kinerja}

Menurut Werther dan Davis dalam Suwatno dan Priansa (2013:197), penilaian kinerja mempunyai beberapa tujuan dan manfaat bagi perusahaan dan karyawan yang dinilai, antara lain:

a. Peningkatan Kinerja (Performance Improvement) Memungkinkan karyawan dan manajer untuk mengambil tindakan yang berhubungan dengan peningkatan kinerja. 
b. Penyesuaian Kompensasi (Compensation Adjustment) Membantu para pengambil keputusan untuk menentukan siapa saja yang berhak menerima kenaikan gaji atau sebaliknya.

c. Keputusan Penempatan (Placement Decision) Menentukan promosi, transfer, dan demotion.

d. Kebutuhan Penegmbangan dan Pelatihan (Training and Development Needs) Mengevaluasi kebutuhan pelatihan dan pengembangan bagi karyawan agar kinerja mereka lebih optimal.

e. Perencanaan dan Pengembangan Karir (Carrer Planning and Development) Memandu untuk menentukan jenis karier dan potensi karier yang dicapai.

f. Prosedur Perekrutan (Process Deficiencies) Mempengaruhi prosedur perekrutan karyawan.

g. Kesalahan Desain Pekerjaan dan Ketidakakuratan informasi (Informational Inaccuracies and Job Design Errors) Membantu menjelaskan apa saja kesalahan yang telah terjadi dalam manajemen sumber daya manusia terutama bidang informasi job analysis, job design, dan sistem informasi manajemen sumber daya manusia.

h. Kesempatan yang Sama (Equal Employment Opportunity) Menunjukan bahwa placement decision tidak diskriminatif.

i. Tantangan Ekternal (Exrernal Challenges) Kadang-kadang kinerja karyawan dipengaruhi oleh faktor eksternal seperti keluarga, keuangan pribadi, kesehatan, dan lain-lain.

j. Umpan Balik (Feddback) Memberikan umpan balik bagi urusan kekaryawanan maupun bagi karyawan itu sendiri. 


\subsubsection{Indikator Kinerja Karyawan}

Beberapa indikator kinerja karyawan yang digunakan dalam penelitian ini adalah sebagai berikut (Robbins 2006):

1) Kualitas

2) Kuantitas

3) Ketepatan Waktu

4) Efektivitas

5) Kemandirian

Indikator Kinerja karyawan menurut (Malthis dan Jackson, 2006):

a. Kualitas Kerja

Standar ini dilakukan dengan cara membandingkan antara besarnya volume kerja yang seharusnya (Standart kerja norma) dengan kemampuan sebenarnya.

b. Kuantitas Kerja

Standart ini menekankan pada mutu kerja yang dihasilkan dibandingkan volume kerja.

c. Ketepatan Waktu

Ketepatan waktu adalah penggunaan masa kerja yang disesuaikan dengan kebijaksanaan perusahaan.

Indikator menurut Mangkunegara, (2003:134) indikator-indikator kinerja terdiri dari:

1. Kualitas kerja.

2. Tepat Waktu.

3. Displin.

4. Pengetahuan tentang pekerjaan

5. Keyakinan. 


\section{Optimisme}

\subsubsection{Kompensasi}

Kompensasi merupakan sesuatu yang diterima karyawan sebagai pengganti kontribusi jasa mereka pada perusahaan. Pemberian kompensasi merupakan pelaksanaan fungsi manajemen sumber daya manusia yang berhubungan dengan semua jenis pemberian harga individual. Menurut Sedarmayanti (2010:239), kompensasi adalah segala sesuatu yang diterima oleh karyawan sebagai balas jasa mereka. Selanjutnya, Dessler (2007:85) menemukakan kompensasi karyawan adalah setiap bentuk pembayaran atau imbalan yang diberikan kepada karyawan dan timbul dari dipekerjakannya karyawan.

From the above opinion it can be synthesized that the compensation is any kind of financial or non-financial rewards either directly or indirectly received by an employee or individual in exchange for the performance of the task of the organization(Onsardi,dkk 2017). Bermakna kompensasi adalah segala bentuk finansial atau non-finansial hadiah baik secara langsung atau tidak langsung diterima oleh karyawan atau individu sebagai imbalan atas kinerja tugas organisasi.

Pada dasarnya kompensasi dikelompokkan kedalam dua kelompok, yaitu kompensasi financial dan kompensasi non financial. Selanjutnya kompensasi financial ada yang langsung dan ada yang tidak langsung, sedangkan kompensasi non financial dapat berupa pekerjaan dan lingkungan pekerjaan. Menurut Sofiyandi (2008), kompensasi financial adalah kompensasi yang diberikan kepada karyawan sebagai imbalan jasa atas pekerjaan yang dilakukan untuk perusahaan.

Selain kompensasi dalam bentuk financial, kompensasi juga berbentuk non financial. Menurut Sutrisno (2009), kompensasi non financial adalah kompensasi yang 
tidak dapat dirasakan secara langsung oleh karyawan. Rivai (2004, p. 358), menyatakan bahwa kompensasi non financial terdiri dari fasilitas perusahaan, pujian, rasa nyaman dalam bekerja, peluang promosi jabatan, motivasi dari perusahaan, lingkungan pekerjaan.

Kompensasi menurut Hasibuan, (2009:118), yaitu kompensasi adalah semua pendapatan yang berbentuk uang, barang langsung atau tidak langsung yang diterima karyawan sebagai imbalan jasa yang diberikan kepada perusahaan.Kompensasi kompensasi berbentuk uang artinya kompensasi dibayar dengan sejumlah uang kartal kepada karyawan yang bersangkutan.sedangkan kompensasi berbentuk barang yaitu kompensasi yang dibayar dengan menggunakan barang.

Berdasarkan teori-teori diatas dapat disimpulkan bahwa kompensasi yaitu semua imbalan yang diterima oleh seorang pekerja atas jasa atau hasil kerjanya pada sebuah organisasi atau perusahaan dimana imbalan tersebut dapat berupa uang ataupun barang, baik langsung ataupun tidak langsung.

\subsubsection{Tujuan Kompensasi}

Menurut S.P Hasibuan (2013:121) adalah sebagai berikut :

1. Ikatan kerja sama, dengan pemberian kompensasi terjalinlah ikatan kerjasama formal anatar batasan dengan karyawan. Karyawan harus mengerjakan tugasnya dengan baik, sedangkan pengusaha atau atasan wajib membayar kompensasi sesuai dengan perjanjian yang telah di sepakati.

2. Kepuasan kerja, dengan balas jasa karyawan akan dapat memenuhi kebutuhan fisik, status social, dan egostiknya sehingga memperoleh kepuasan kerja dari jabatannya.

3. Pengadaan efektif, jika program kompensasi ditetapkan cukup besar, pegadaan karyawan yang qualifield untuk perusahaan akan lebih mudah. 
4. Motivasi, jika balas jasa yang diberikan cukup besar, manajer akan lebih mudah memotivasi bawahannya.

5. Stabilitas karyawan, dengan program kompensasi atas prinsip adil dan layak serta eksternal konsistensi yang kompetitif maka stabilitas karyawan akan lebih mudah terjamin karena turnover relative kecil.

6. Displin, dengan pemberian balas jasa yang cukup besar maka displin karyawan semakin membeik, mereka akan menyadari serta menaati peraturan-peraturan yang berlaku.

7. Pengaruh serikat buruh, dengan program kompensasi yang baik pengaruh serikat buruh dapat dihindarkan dan karyawan akan berkonsentrasi pada pekerjaannya.

8. Pengaruh pemerintah, jika programa kompensasi sesuai dengan undang-undang perburuhan yang berlaku ( seperti batas upah minimum) maka intervensi pemerintahan dapat dihindarkan.

Menurut pendapat Ardana (2012:155), sistem pembayaran kompensasi antara lain:

1. Sistem Waktu

a. Kompensasi (gaji, upah) besarnya ditetapkan berdasarkan standar waktru seperti : jam, hari, minggu atau bulan.

b. Administrasi pengupahannya relative mudah dapat diterapkan pada kryawan tetap maupun kepada pekerja harian.

c. Sistem ini diterapkan jika prestasi kerja sulit diukur per unitnya dan bagi karyawan tetap kompensasinya dibayarkan atas sistem waktu secara periode setiap bulannya.

d. Besarnya kompensasi hanya didasarkan kepada lamanya bekerja, bukan dikaitkan dengan prestasi kerjanya. 


\section{Sistem Hasil}

a. Kompensasi atau upah yang ditetapkan atas kesatuan unit yang dihasilkan pekerja, seperti per potong, meter, liter, kilo gram.

b. Kompensasi yang dibayar selalu didasarkan pada banyaknya hasil yang dikerjakan bukan kepada lamanya waktu mengerjakannya.

c. Tidak dapat ditetapkan pada karyawan tetap, dan jenis pekerjaan yang tidak mempunyai standar fisik seperti karyawan administrasi.

3. Sistem Borongan

a. Suatu cara pengupahan yang penempatannya penetapan besarnya jasa didasarkan atas volume pekerjaan dan lamanya mengerjakannya.

b. Penetapan besarnya balas jasa berdasarkan sistem ini cukup rumit, lama mengerjakannya serta berapa banyak alat yang diperlukan untuk menyelesaikannya.

c. Dalam sistem borongan memerlukan kalkulasi yang tepat untuk memperoleh balas jasa yang wajar, perhitungan-perhitungan yang tepat.

\subsubsection{Indikator Kompensasi}

Kompensasi adalah penghargaan yang diberikan dalam bentuk financial kepada karyawan sebagai balas jasa atas kontribusi yang mereka berikan kepada organisasi. Menurut Atmajawati (2007:21) indikator Kompensasi terdiri atas :

1. Gaji adalah merupakan imbalan balik perusahaan terhadap karyawan atas kerja mereka.

2. Insentif adalah kompensasi diluar gaji dan upah yang diberikan organisasi atas prestasi kerja mereka yang memenuhi target. 
3. Tunjangan adalah kebijakan perusahaan terhadap karyawan berdasar loyalitas karyawan dalam meningkatkan kesejahteraan karyawan.

Indikator kompensasi menurut, Onsardi, dkk (2017) terdiri atas:

(1) gaji dan insentif,

(2) tunjangan,

(3) penghargaan.

Menurut Yamoah (2013: 60),indikator Kompensasi adalah sebagai berikut:

1. Imbalan kerja

Menurut Becker \& Gerhart dalam Yamoah (2013: 60) Imbalan kerja adalah hadiah langsung yang diberikan kepada seorang atau kelompok karyawan sebagai bagian dari keanggotaan organisasi. Imbalan kerja termasuk jaminan keamaan, jaminan kesehatan seperti imbalan saat sakit, jaminan pendidikan, imbalan hari libur, imbalan liburan dan ketidakhadiran.

Menurut Storey dalam Yamoah (2013: 60) keuntungan dari imbalan kerja untuk organisasi adalah untuk membantu organisasi untuk menarik dan mempertahankan karyawan yang memiliki kinerja yang baik. Organisasi dapat mempertahankan karyawan yang memiliki kinerja yang baik karena karyawan akan termotivasi dan memiliki komitmen terhadap organisasi.

2. Kompensasi dasar

Menurut Boxal dalam Yamoah (2013: 60), kompensasi dasar yang seorang karyawan menerima adalah disebut gaji pokok. Oleh karena itu, gaji pokok adalah tingkat standar gaji tidak memiliki apapun penambahan dibuat untuk itu. Banyak organisasi menggunakan kategori gaji pokok seperti per jam dan gaji. Kategori ini diidentifikasi sesuai dengan cara membayar didistribusikan dan sifat dari pekerjaan. 
Karyawan yang dibayar per jam menerima apa yang disebut upah. Upah ini dihitung pada jumlah waktu bekerja. Karyawan yang dibayar secara konsisten dari periode ke periode seperti setiap tahun, mingguan atau bulanan menerima apa yang disebut sebagai gaji.

\section{Imbalan Non Keuangan}

Ini termasuk imbalan yang berfokus pada kebutuhan orang untuk berbagai tingkat untuk prestasi, pengakuan, tanggung jawab, pengaruh dan pertumbuhan pribadi. Menurut Armstrong dalam Yamoah (2013: 60), imbalan non-keuangan yang tidak melibatkan pembayaran langsung dan sering timbul dari pekerjaan itu sendiri, misalnya, prestasi, otonomi, dan pengakuan, ruang lingkup untuk menggunakan dan mengembangkan keterampilan, pelatihan, peluang pengembangan karir dan kepemimpinan yang berkualitas tinggi. Selain imbalan diberikan kepada karyawan, pengusaha juga harus berkonsentrasi pada aspek non moneter. Karyawan harus diberikan ruang untuk mengekspresikan pandangan mereka.

Pengusaha juga harus melibatkan karyawan dalam pengambilan keputusan. Organisasi harus memastikan bahwa karyawan dapat mengembangkan karir mereka dengan membawa mereka melalui pelatihan dan pengembangan. Lingkungan kerja harus kondusif bagi karyawan agar mereka merasa bagian dari organisasi tersebut.

\subsubsection{Pelatihan Kerja}

Mangkunegara (2008:50) mengemukakan bahwa pelatihan adalah suatu proses pendidikan jangka pendek yang mempergunakan prosedur sistematis dan terorganisir di mana pegawai non-managerial memepelajari pengetahuan dan ketrampilan teknis dalam tujuan terbatas. 
Menurut Gary Dessler (2015:263) pelatihan kerja merupakan proses mengajarkan pegawai baru atau yang sudah ada sekarang, keterampilan dasar yang mereka butuhkan untuk menjalankan perkerjaan mereka. Pelatihan merupakan salah satu usaha dalam meningkatkan mutu sumber daya manusia dalam dunia kerja baik pegawai yang baru ataupun yang sudah bekerja perlu mengikuti pelatihan.

Pelatihan dapat diartikan sebagai proses pendidikan jangka pendek dengan menggunakan prosedur sistematik pengubahan perilaku dalam satu arah guna meningkatkan tujuan-tujuan organisasional. Menurut Davis dan Werther dalam Sedarmayanti (2010: 164). Training prepares people to do their present job and development prepares employess needed knowledge, skill and attitude”. Artinya, bahwa pelatihan mempersiapkan orang untuk melakukan pekerjaan mereka sekarang dan pengembangan mempersiapkan pegawai yang membutuhkan pengetahuan, keterampilan dan sikap.

Education and training are one of the traditional functions of human resource management that will be able to improve employee performance or achievement (Sutrisno, 2011: 151).bermkna yaitu Pendidikan dan latihan adalah salah satu fungsi tradisional manajemen sumber daya manusia yang akan dapat ditingkatkan kinerja atau pencapaian karyawan (Sutrisno, 2011: 1 51).

Menurut kaswan (2011:2), "Pelatihan adalah proses meningkatkan pengetahuan dan keterampilan karyawan".

Berdasarkan teor-teori diatas dapat disimpulkan bahwa pelatihan kerja yaitu proses pendidikan dalam jangka pendek dengan tujuan untuk memenuhi kebutuhan organisasi dan mencapai tujuan organisasi.

\subsubsection{Tujuan Pelatihan}


Tujuan-tujuan pelatihan menurut Simamora dalam Hartatik (2014:89) adalah sebagai berikut:

a. Memperbaiki kinerja karyawan yang tidak memuaskan karena kekurangan keterampilan.

b. Memutakhiran keahlian para karyawan sejalan dengan kemajuan teknologi.

c. Mengurangi waktu pembelajran bagi karyawan baru agar kompeten dalam bekerja.

d. Membantu memecahkan masalah operasional.

e. Mempersiapkan karyawan untuk promosi.

f. Mengorientasikan karyawan baru terhadap organisasi.

g. Mengetahui kebutuhan pertumbuhan pribadi

\subsubsection{Manfaat Pelatihan}

Menurut simamora dalam Hartatik (2014:91) terdapat beberapa manfaat yang didapat deprogram pelatihan, yaitu sebagai berikut:

a. Meningkatkan kuantitas dan kualitas produktivitas.

b. Mengurangi waktu belajar yang diperlukan karyawan untuk mencapai standar kinerja yang dapat diterima.

c. Membentuk sikap, loyalitas, dan kerja sama yang lebih menguntungkan.

d. Memenuhi kebutuhan perencanaan sumber daya manusia.

e. Mengurangi frekuensi dan biaya kecelakaan kerja.

f. Membantu karyawan dalam meningkatkan dan mengembangkan pribadi mereka

\subsubsection{Metode Pelatihan}

Dalam pelatihan terdapat beberapa metode antara lain : metode on the job training yaitu pelatihan yang diberikan secara langsung dan memberikan karyawan baru 
kecakapan yang diperlukan untuk suatu pekerjaan tertentu. Pengawasan dan instruksi langsung dberikan pesertanya di tempat kerja serta metode off the job training yaitu pelatihan yang dilaksanakan secara khusus diluar tempat pekerjaan.

\subsubsection{Materi Pelatihan}

Materi pelatihan memiliki peranan yang penting dalam penyelenggaraan training yang efektif.Meskipun sering dilakukan setiap periode perekrutan atau secara berkelanjutan, pelatihan yang ditujukan untuk karyawan tetap harus dipersiapkan dengan sebaik-baiknya.Dibutuhkan perencanaan yang baik dalam penyusunan materi agar dapat menjawab kebutuhan dan memberikan hasil yang tepat.

Terdapat tiga tahapan utama dalam pelaksanaan training yang efektif, yaitu :

\section{Sebelum Pelatihan}

\section{Saat Pelatihan Berlangsung}

\section{Pasca Pelatihan}

Pembuatan materi pelatihan harus dibuat seefektif mungkin sehingga peserta pelatihan dapat dengan mudah memahami maksud dan tujuan diadakannya pelatihan tersebut. Materi pelatihan yang panjang dan membosankan akan membuat peserta pelatihan kurang memahami isi dari pelatihan tersebut sehingga, pelatihan yang dilakukan oleh perusahaan tidak berhasil. Dari prinsip-prinsip pembuatan materi pelatihan tersebut, dapat disimpulkan bahwa materi pelatihan akan berpengaruh terhadap kelancaran proses pelatihan. Materi yang baik akan memenuhi kriteria serta prinsipprinsip penulisan materi pelatihan.

\subsubsection{Indikator Pelatihan}

Rivai dan Sagala (2013, p. 226) menyebutkan beberapa indikator pelatihan meliputi: 
1. kualitas materi pelatihan

2. kualitas metode pelatihan

3. kualitas instruktur pelatihan,

4. kualitas sarana dan fasilitas pelatihan

5. kualitas peserta pelatihan.

Indikator untuk mengukur kesuksesan pelatihan menurut kesuksesan pelatihan menurut Sultana et al, (2012) dan sinambela (2012) yaitu:

1. Pengembangan pengetahuan

2. Keterampilan

3. Kemampuan

4. Kompetensi

5. Perilaku

Indikator untuk mengukur kesuksesan pelatihan menurut Mangkunegara (2008) terdiri atas:

1. Kriteria pendapat

2. Kriteria belajar

3. Kriteria perilaku

4. Kriteria hasil

\subsubsection{Kepuasan Kerja}

Kepuasan Kerja (Titisari, 2014:18) adalah suatu ungkapan perasaan atau sikap seseorang terhadap pekerjaannya, terhadap kesempatan promosi, hubungan dengan rekan kerja, pengawasan dan perasaan puas terhadap pekerjaan itu sendiri. Kepuasan kerja lebih mencerminkan sifat daripada perilaku. Menurut Handoko (2001:193) menjelaskan bahwa 
kepuasan kerja adalah keadaan emosional yang menyenangkan ketika para karyawan menjalankan pekerjaannya masing-masing.

Robbins dan Judge (2015) menjelaskan "Kepuasan kerja (job satisfaction) adalah suatu perasaan positif tentang pekerjaan, yang dihasilkan dari suatu evaluasi dari karakteristik-karakteristiknya”.

Menurut Wirawan (2013:698), kepuasan kerja adalah persepsi orang mengenai berbagai aspek dari pekerjaannya. Persepsi dapat berupa perasaan dan sikap orang terhadap pekerjaannya.Perasaan dan sikap dapat positif atau negatif. Jika seseorang bersikap positif terhadap pekerjaannya, maka ia puas terhadap pekerjaannya, sebaliknya, jika karyawan bersikap negatif terhadap pekerjaannya maka ia tidak puas terhadap pekerjaannya.

According Colquitt, et al, (2013) Job satisfaction is defined as a pleasurable emotional state resulting from the appraisal of one's job or job experiences. Robbins dan Judge (2015) explains that job satisfaction is a positive feeling about a job, resulting from an evaluation of its characteristics. Then Luthans (2011) explain job satisfaction a pleasurable or positive emotional state resulting from the appraisal of one's job or job experience. Job satisfaction is a result of employees perception of how well their job provide those thing that are viewed as important.

Menurut Colquitt, et al, (2013) Kepuasan kerja didefinisikan sebagai kondisi emosional yang menyenangkan yang dihasilkan dari penilaian pekerjaan atau pengalaman kerja seseorang. Robbins dan Judge (2015) menjelaskan bahwa kepuasan kerja adalah perasaan positif tentang pekerjaan, yang dihasilkan dari evaluasi karakteristiknya. Kemudian Luthans (2011) menjelaskan kepuasan kerja keadaan emosional yang menyenangkan atau positif yang dihasilkan dari penilaian pekerjaan atau pekerjaan seseorang pengalaman. Kepuasan kerja adalah hasil dari persepsi karyawan tentang seberapa baik pekerjaan mereka menyediakan hal-hal itu dipandang penting. 
Kepuasan kerja (Badriyah, 2015:227). merupakan salah satu faktor yang sangat penting untuk mendapatkan hasil kerja yang optimal. Ketika seseorang merasa puas dalam bekerja, maka ia akan berupaya semaksimal mungkin dengan segenap kemampuan yang dimilikinya untuk menyelesaikan tugas pekerjaan tersebut. Dengan demikian, produktivitas dan hasil kerjanya akan meningkat secara optimal

Berdasarkan Teori-Teori Diatas Dapat Disimpulkan bahwa kepuasan kerja yaitu tingkat kesenangan yang dirasakan seseorang atas peranan atau pekerjaanya dalam organisasi.

\subsubsection{Faktor-faktor yang mempengaruhi kepuasan kerja}

Menurut Sutrisno (2014:80) mengatakan faktor-faktor yang mempengaruhi kepuasan kerja yaitu:

a. Faktor psikologis, merupakan faktor yang berhubungan dengan kejiwaan karyawan yang meliputi: minat, nyaman dalam kerja, sikap terhadap kerja, bakat, dan keterampilan.

b. Faktor social, merupakan faktor yang berhubungan dengan interaksi social baik antara sesame karyawan maupun dengan atasannya.

c. Faktor fisik, merupakan faktor yang berhubungan dengan kondisi fisik karyawan, meliputi : jenis pekerjaan, pengaturan waktu dan waktu istirahat, perlengkapan kerja, keadaan ruangan (suhu, penerangan, pertukran udara ), kondisi kesehatan karyawan, umur, dan sebagainya.

d. Faktor financial, merupakan faktor yang berhubungan dengan jaminan serta kesejahteraan karyawan yang meliputi: sistem dan besarnya gaji, jaminan social macam-macam tunjangan, fasilitas yang diberikan promosi dan sebagainya. 
Adapun faktor-faktor mempengaruhi Teori-teori kepuasan kerja menurut Mangkunegara (2000) antara lain :

\section{Teori Keseimbangan (Equity Theory)}

Teori ini dikembangkan oleh Adam. Adapun komponen dari teori ini adalah input, outcome, comparison person, dan equity-in-equity. Input adalah semua nilai yang diterima karyawan yang dapat menunjang pelaksanaan kerja. Misalnya pendidikan , pengalaman, skill, usaha, peralatan pribadi dan jumlah jam kerja.

\section{Teori Perbedaan (Discrepancy Theory)}

Teori ini pertama kali dipelopori oleh Porter.Ia berpendapat bahwa mengukur kepuasan dapat dilakukan dengan cara menghitung selisih antara apayang seharusnya dengan kenyataan yang dirasakan karyawan. Locke mengemukakan bahwa kepuasan kerja karyawan tergantung pada perbedaan antara apa yang didapt dan apa yang diharapkan oleh karyawan. Apabila yang didapat karyawan ternyata lebih besar daripada apa yang diharapkan maka karyawan tersebut menjadi puas. Sebaliknya, apabila yang didapat karyawan lebih rendah daripada yang diharapkan, akan menyebabkan karyawan tidak puas.

\section{Teori Pemenuhan Kebutuhan (Need Fulfillment Theory)}

Teori ini pertama kali dipelopori A. H. Maslow.dikemukakan oleh A. H.Maslow tahun 1943. Teori ini merupakan kelanjutan dari “Human Science Theory”Elton Mayo (1880-1949) yang menyatakan bahwa kebutuhan dan kepuasanseseorang itu jamak, yaitu kebutuhan biologis dan psikologis berupa kebutuhanmateriil dan non-materiil.Teori ini pertama kali dipelopori A. H. Maslow.dikemukakan oleh A. H.Maslow tahun 1943. Teori ini merupakan kelanjutan dari “Human Science Theory”'Elton Mayo (1880-1949) yang 
menyatakan bahwa kebutuhan dan kepuasanseseorang itu jamak, yaitu kebutuhan biologis dan psikologis berupa kebutuhanmateriil dan non-materiil.

\section{Teori Pandangan Kelompok (Social Reference Group Theory)}

Menurut teori ini, kepuasan kerja karyawan bukanlah bergantung pada pemenuhan kebutuhan saja, tetapi sangat bergantung pada pandangan dan pendapat kelompok yang oleh para karyawan dianggap sebagai kelompok acuan.Kelompok acuan tersebut oleh karyawan dijadikan tolak ukur untuk menilai dirinya maupun lingkungannya. Jadi karyawan akan merasa puas apabila hasil kerjanya sesuai dengan minat dan kebutuhan yang diharapkan oleh kelompo acuan.

\section{Teori Pengharapan (Ecpentancy Theory)}

Teori pengharapan dikembangkan oleh Victor H. Vroom.Kemudian teori ini diperluas oleh Porter dan Lawyer. Vroom menjelaskan bahwa motivasi suatu produk dari bagaimana seseorang menginginkan sesuatu dan penaksiran seseorang memungkinkan aksi tertentu yang akan menuntunnya.

\section{Teori Dua Faktor Herzberg (Herzberg's Two Factor Theory)}

Dua faktor yang dapat menyebabkan timbulnya rasa puas atau tidak puas menurut Herzberg, yaitu faktor pemeliharaan (maintenance factors) dan factor pemotivasian (motivational factors). Factor pemeliharaan disebut pula dissatisfiers, hygiene factors, job context, extrinsic factors yang meliputi administrasi dan kebijakan perusahaan, kualitas pengawasan, hubungan dengan pengawas, hubungan dengan sub ordinat, upah, keamanan kerja, kondisi kerja dan status .sedangkan faktor pemotivasian disebut pula satisfier, motivators, job, content, intrinsic factor yang meliputi dorongan berprestasi , pengenalan, kemajuan (advancement), kesempatan berkembang dan tanggung jawab. 
Ada lima faktor penentu kepuasan kerja yang disebut dengan Job Descriptive Index (JDI) (Luthans dan Spector dalam Robins 2006), yaitu :

1) Pekerjaan itu sendiri

Tingkat dimana sebuah pekerjaan menyediakan tugas yang menyenangkan, kesempatan belajar dan kesempatan untuk mendapatkan tanggung jawab.Hal ini menjadi sumber mayoritas kepuasan kerja.

Menurut Locke, ciri-ciri intrinsic yang menentukan kepuasan kerja adalah keragaman, kesulitan, jumlah pekerjaan, tanggung jawab, otonomi, kendali terhadap metode kerja, kemajemukan dan kreativitas.

\section{2) Gaji}

Menurut penelitian Theriault, kepuasan kerja merupakan fungsi dari jumlahabsolute dari gaji yang diterima, derajad sejauh mana gaji memnuhi harapanharapantenaga kerja, dan bagaimana gaji diberikan, upah dan gaji diakui merupakan faktor yang signifikan terhadap kepuasan kerja.

3) Kesempatan atau promosi

Karyawan memiliki kesempatan untuk mengembangkan diri dan memperluas pengalaman kerja, dengan terbukanya kesempatan untuk kenaikan jabatan.

4) Supervisior

Kemampuan supervisior untuk menyediakan bantuan teknis dan perilaku dukungan. Menurut Locke, hubungan fungsional dan hubungan keseluruhan yang positif memberikan tingkat kepuasan kerja yang paling besar dengan atasan.

5) Rekan Kerja 
Kebutuhan dasar manusia untuk melakukan hubungan social akan terpenuhi dengan adanya rekan kerja yang mendukung karyawan. jika terjadi konflik dengan rekan kerja , maka akan berpengaruh pada tingkat kepuasan karyawan

terhadap pekerjaan.

\subsubsection{Indikator Kepuasan Kerja}

Tolak ukur kepuasan kerja yang mutlak sulit untuk dicari karena setiap individu karyawan berbeda standar kepuasannya.

Adapun indikator-indikator kepuasan kerja menurut Luthans(2007)antara lain :

1. Kepuasan terhadap pembayaran gaji atau upah.

2. Kepuasan terhadap pekerjaan itu sendiri.

3. Kepuasan terhadap rekan kerja.

4. Kepuasan terhadap promosi.

5. Kepuasan terhadap pengawasan kerja.

Robbins (2010:149) lima indicator yang dapat menjadi tolak ukur kepuasan kerja, antara lain:

1. Kepuasan dengan gaji

2. Kepuasan dengan promosi

3. Kepuasan dengan rekan kerja

4. Kepuasan dengan atasan

5. Kepuasan dengan pekerjaan itu sendiri

Spector (Priansa, 2016:292) Dan ia dapat mengidentifikasikan indikator kepuasan kerja dari sembilan aspek yaitu:

1. Gaji 
Aspek ini mengukur kepuasan pegawai sehubungan dengan gaji yang diterimanya dan adanya kenaikan gaji, yaitu besarnya gaji yang diterima sesuai dengan tingkat yang dianggap sepadan. Upah dan gaji memang mempunyai pengaruh terhadap kepuasan kerja. Upah dan gaji juga menggambarkan berbagai dimensi dari kepuasan kerja. Pegawai memandang gaji sebagai hak yang harus diterimanya atas kewajiban yang sudah dilaksanakannya.

\section{Promosi}

Aspek ini mengukur sejauh mana kepuasan pegawai sehubungan dengan kebijaksanaan promosi dan kesempatan untuk mendapatkan promosi. Promosi atau kesempatan untuk meningkatkan karier juga memberikan pengaruh terhadap kepuasan kerja pegawai.

Pegawai akan melihat apakah organisasi memberikan kesempatan yang sama kepada setiap pegawainya untuk mendapatkan kenaikan jabatan ataukah hanya diperuntukkan bagi sebagian orang saja. Kebijkasanaan promosi ini harus dilakukan secara adil, yaitu setiap pegawai yang melakukan pekerjaan dengan baik mempunyai kesempatan yang sama untuk promosi.

3. Supervisi (hubungan dengan atasan)

Aspek ini mengukur kepuasan kerja seseorang terhadap atasannya. Pegawai lebih menyukai bekerja dengan atasan yang bersikap mendukung, penuh perhatian, hangat dan bersahabat, memberi pujian atas kinerja yang baik dari bawahan, mendengar pendapat dari bawahan, dan memusatkan perhatian kepada pegawai (employed centered) dari pada bekerja dengan pimpinan yang bersifat acuh tak acuh, kasar, dan memusatkan dirinya kepada pekerjaan (job centered). 


\section{Tunjangan Tambahan}

Aspek ini mengukur sejauhmana individu merasa puas terhadap tunjangan tambahan yang diterimanya dari organisasi. Tunjangan tambahan diberikan kepada pegawai secara adil dan sebanding.

\section{Penghargaan}

Aspek ini mengukur sejauhmana individu merasa puas terhadap penghargaan yang diberikan berdasarkan hasil kerja. Setiap individu ingin usaha, kerja keras, dan pengabdian yang dilakukannya untuk kemajuan organisasi dapat dihargai dengan semestinya.

\section{Prosedur dan Peraturan Kerja}

Aspek ini mengukur kepuasan sehubungan dengan prosedur dan peraturan di tempat kerja. Hal-hal yang berhubungan dengan prosedur dan peraturan di tempat kerja mempengaruhi kepuasan kerja seorang individu, seperti birokrasi dan beban kerja.

\section{Rekan kerja}

Aspek ini mengukur kepuasan kerja berkaitan dengan hubungan dengan rekan kerja. Rekan kerja yang memberikan dukungan terhadap rekannya yang lain, serta suasana kerja yang nyaman dapat meningkatkan kepuasan kerja pegawai. Misalnya rekan kerja yang menyenangkan atau hubungan dengan rekan kerja yang rukun.

\section{Pekerjaan itu Sendiri}

Aspek yang mengukur kepuasan kerja terhadap hal-hal yang berkaitan dengan pekerjaan itu sendiri, seperti kesempatan untuk berekreasi dan variasi dari tugas, kesempatan untuk menyibukkan diri, peningkatan pengetahuan, tanggung jawab, otonomi, pemerkayaan pekerjaan, dan kompleksitas pekerjaan.

\section{Komunikasi}


Aspek ini mengukur kepuasan yang berhubungan dengan komunikasi yang berlangsung dalam pekerjaan. Dengan komunikasi yang berlangsung lancar dalam organisasi, pegawai dapat lebih memahami tugas-tugasnya dan segala sesuatu yang terjadi di dalam organisasi.

\subsubsection{Pengaruh Antar Variabel}

\subsubsection{Pengaruh Kompensasi Terhadap Kinerja Karyawan}

Secara historis, karyawan yang mendapatkan kompensasi yang hingga mendapatkan kepausan kerja, sehingga akan meningkatkan kmerjanya dengan lebih baik. Yang perlu diperhatikan dari manajemen sumber daya manusia iakh bagaimana mengkomunikasikan strategi perusahaan yang baik sehingga kesejahteraan karyawan dapat ditingkatkan melalui sistem penggajian yang ada. Kompensasi yang kurang akan menimbulkan ketidakpuasan kerja yang berdampak pada turunnya daya tarik pekerjaan, terjadi perputaran karyawan dan meningkatkan absensi Ketidakpuasan ini akhirnya menimbulkan stres pada karyawan dan menurunkan kinerja (Zammuto, 2009; 129).

Karyawan akan kehikngan persepsi terhadap perusahaan. Ini biasanya ditandai dengan keluhan berkepanjangan soal minimnya gaji yang diterima, yang lama kelamaan akan menimbulkan mogok kerja. Hubungan antara kompensasi dan kinerja juga dijelaskan dalam teori pengharapan yang mengatakan bahwa seseorang akan mengehiarkan npaya-upaya tingkat tinggi untuk kinerjanya, apabila dengan tingkat kinerjanya yang tinggi diperoleh ganjaran (kompensasi) sesuai pengharapan (Robbins, 2008:189).

Kompensasi menurut,Handoko (2010:156).merupakan salah satu faktor penting yang dapat menentukan kinerja karyawan. Bila pengupahan dan penggajian tidak diadmmistrasikan secara tepat, perusahaan bisa kehilangan para karyawannya yang baik, 
bahkan biob karyawan tidak kehiar, mereka mungkin menjadi tidak puas terhadap perusahaan dan menurunkan kinerja dan produktivitas mereka

Menurut Sjafri (2009), kketerkaitan kompensasi dengan kinerja karyawan sangatlah signifikan. Semakin tinggi kompensasi semakin tinggi tingkat kepuasan kerja karyawan. Derajat kepuasan yang semakin tinggi akan semakin meningkatkan motivasi karyawan dalam meraih kinerja yang tinggi. Jika dikelola dengan baik, kompensasi membantu perusahaan untuk mencapai tujuan dalam memperoleh, memelihara, dan menjaga karyawan dengan optimum.

Berdasarkan uraian tersebut, maka hipotesis kedua yang diajukan pada penelitian ini adalah sebagai berikut :

H1: Kompensasi berpengaruh positif dan signifikan terhadap kinerja karyawan.

\subsubsection{Pengaruh Pelatihan Kerja Terhadap Kinerja Karyawan}

Pelatihan yang diberikan instanti kepada karyawan berisi tentang hal-hal yang terkait dengaan pekerjaan yang dimiliki oleh karyawan tersebut. Pelatihan yang baik akan menjelaskan secara detail bagaimana suatu pekerjaan harus diselesaikan dan bagaimana prosesnya. Jika karyawan sudah memahami dan menguasai proses pekerjaan yang dia miliki, maka kinerja karyawan juga akan meningkat karena karyawan tersebut akan lebih mudah dalam mengerjakan pekerjaannya. Hal ini sesuai dengan penelitian yang dilakukan oleh Hamalik (2007: 10), pelatihan adalah suatu proses yang meliputi serangkaian tindak (upaya) yang dilaksanakan dengan sengaja dalam bentuk pemberian bantuan kepada tenaga kerja yang dilakukan oleh tenaga profesional kepelatihan dalam satuan waktu yang bertujuan untuk meningkatkan kemampuan kerja peserta dalam bidang pekerjaan tertentu guna meningkatkan efektivitas dan produktivitas dalam suatu organisasi. 
Pelatihan berpengaruh signifikan terhadap kinerja karyawan. Hasil penelitian ini konsisten dengan penelitian yang dilakukan Oktavianto (2011) yang menyatakan bahwa pelatihan berpengaruh signifikan terhadap kinerja karyawan. Pelatihan bagi karyawan sangat penting untuk diterapkan dalam suatu instansi. Dengan adanya pelatihan diharapkan karyawan akan dapat bekerja secara lebih efektif dan efisien terutama untuk menghadapi perubahan-perubahan yang terjadi seperti perubahan teknologi, perubahan metode kerja, menuntut pula perubahan sikap, tingkah laku, ketrampilan dan pengetahuan. Oleh karena itulah perusahaan yang ingin berkembang, maka pelatihan bagi karyawannya harus mendapatkan perhatian yang besar. Dengan demikian dapat dikatakan bahwa tujuan pelatihan adalah untuk mengembangkan pengetahuan, sikap, dan ketrampilan kerja dalam usahanya untuk meningkatkan kinerja karyawan sehingga menghasilkan produk yang berkualitas. Di samping itu juga untuk menutup kesenjangan antara kemampuan kerja karyawan dengan tuntutan pekerjaan. Sehingga akan tercapai suatu kondisi yang saling menguntungkan baik bagi perusahaan maupun bagi karyawan. Pelatihan yang diberikan perusahaan kepada karyawan berisi tentang hal-hal yang terkait dengaan pekerjaan yang dimiliki oleh karyawan tersebut. Pelatihan yang baik akan menjelaskan secara detail bagaimana suatu pekerjaan harus diselesaikan dan bagaimana prosesnya. Jika karyawan sudah paham dan menguasai proses pekerjaan yang dia miliki, maka kinerja karyawan juga akan meningkat karena karyawan tersebut akan lebih mudah dalam mengerjakan pekerjaannya. Hal ini sesuai dengan hasil penelitian Rahmah Ismail dan Zulridah Mohd Noor (2010), yang menyatakan bahwa pelatihan kerja berpengaruh secara signifikan untuk mengembangkan pengetahuan, ketrampilan, dan kebiasaan pekerja menjadi lebih baik sehingga kinerja karyawan akan meningkat. 


\subsubsection{Pengaruh Kepuasan Kerja Terhadap Kinerja Karyawan}

Wibowo (2014:170) menyatakan bahwa hubungan yang dimaksud adalah apabila kepuasan karyawan yang berupa keinginan, harapan, tujuan keperluan dan kebutuhan karyawan tersebut terpenuhi, maka akan meningkatkan kinerjanya dalam perusahaan. Demikian juga sebaliknya, apabila kepuasan kerjanya tidak terpenuhi makan kinerjanya pun akan menurun.

Hasil analisis mengungkapkan bahwa kepuasan kerja mempunyai pengaruh yang positif dan signifikan terhadap kinerja karyawan. Hasil penelitian ini sejalan dengan hasil penelitian Merry Ristiana M (2013) yang menunjukkan bahwa hubungan Kepuasan Kerja dengan Kinerja Karyawan memiliki pengaruh yang positif dan signifikan. Hubungan tersebut mengartikan bahwa semakin puas karyawan kepada perusahaan, maka performa kerja dan hasil kerja yang ditunjukkan akan semakin baik atau sebaliknya. Jika seseorang merasakan kepuasan dalam pekerjaannya maka semangat kerjanya akan semakin meningkat. Dorongan tersebut dapat memudahkan untuk mencapai tujuan yang telah ditetapkan oleh perusahaan. Wibowo $(2015: 141)$ berpendapat bahwa kepuasan kerja merupakan prediktor kinerja, karena kepuasan kerja mempunyai korelasi moderat dengan kinerja. Dengan demikian dapat disimpulkan bahwa tinggi rendahnya kepuasan kerja karyawan akan berpengaruh terhadap kinerja. Apabila kepuasan kerja tercapai maka kinerja karyawan akan tinggi, begitupula sebaliknya 
2.2 Hasil Penelitian yang Relevan

\begin{tabular}{|c|c|c|c|}
\hline $\begin{array}{c}\text { Nama } \\
\text { Peneliti }\end{array}$ & Judul & $\begin{array}{l}\text { Metode } \\
\text { Analisis }\end{array}$ & Hasil Penelitian \\
\hline $\begin{array}{l}\text { Adigun A. } \\
\text { O. (Ph.D), } \\
\text { Oyekunie I. A } \\
\text { and Onifade } \\
\text { T.A } \\
2017\end{array}$ & $\begin{array}{ll}\text { Influence Of } & \text { Job } \\
\text { Satisfaction } & \text { On } \\
\text { Employees } & \\
\text { Performance } & \text { In } \\
\text { Mtn Nigeria } & \end{array}$ & $\begin{array}{l}\text { Analisis } \\
\text { Regresi } \\
\text { Linear }\end{array}$ & $\begin{array}{l}\text { This research work has } \\
\text { shown that job } \\
\text { satisfactions have an } \\
\text { influence on } \\
\text { employees' } \\
\text { performance and }\end{array}$ \\
\hline $\begin{array}{l}\text { Any } \\
\text { Isvandiari } \\
(2017)\end{array}$ & $\begin{array}{l}\text { Pengaruh } \\
\text { Kompensasi dan } \\
\text { Disiplin Kerja } \\
\text { Terhadap Kinerja } \\
\text { Karyawan Bagian } \\
\text { Produksi PG. } \\
\text { Meritjan Kediri }\end{array}$ & $\begin{array}{l}\text { Regresi } \\
\text { Linier } \\
\text { Berganda }\end{array}$ & $\begin{array}{l}\text { Hasil penelitian } \\
\text { menunjukkan bahwa } \\
\text { kompensansi }\left(\mathrm{X}_{1}\right) \\
\text { berpengaruh positif } \\
\text { dan signifikan } \\
\text { terhadapkinerja } \\
\text { karyawan }(\mathrm{Y}) \text {. Displin } \\
\text { kerja }\left(\mathrm{X}_{2}\right) \text { berpengaruh } \\
\text { negatif dan signifikan } \\
\text { terhadap kinerja } \\
\text { karyawan }(\mathrm{Y}) .\end{array}$ \\
\hline $\begin{array}{l}\text { Ayu Desi } \\
\text { Indrawati } \\
(2013)\end{array}$ & $\begin{array}{l}\text { Pengaruh } \\
\text { kepuasan kerja } \\
\text { terhadap kinerja } \\
\text { karyawan dan } \\
\text { kepuasan kerja } \\
\text { pelanggan pada } \\
\text { rumah sakit } \\
\text { swasta di kota } \\
\text { denpasar }\end{array}$ & $\begin{array}{l}\text {, Analisis } \\
\text { regresi } \\
\text { linier } \\
\text { berganda }\end{array}$ & $\begin{array}{l}\text { Kepuasan kerja } \\
\text { berpengaruh signifikan } \\
\text { yang positif terhadap } \\
\text { kinerja karyawan, } \\
\text { kinerja karyawan juga } \\
\text { berpengaruh posotif } \\
\text { signifikan terhadap } \\
\text { kepuasan pelanggan } \\
\text { dan kepuasan kerja } \\
\text { berpengaruh positif } \\
\text { secara langsung } \\
\text { terhadap dan tidak } \\
\text { langsung melalui } \\
\text { kinerja karyawan } \\
\text { terhadap kepuasan } \\
\text { pelanggan }\end{array}$ \\
\hline
\end{tabular}




\begin{tabular}{|c|c|c|c|}
\hline $\begin{array}{l}\text { dina kurniati } \\
\text { ( } 2018 \text { ) }\end{array}$ & $\begin{array}{l}\text { Pengaruh } \\
\text { Kompensansi dan } \\
\text { Displin Kerja } \\
\text { Terhadap Kinerja } \\
\text { Karyawandi PT. } \\
\text { Marinal } \\
\text { Indoprima Desa } \\
\text { Kapedi Sumenep }\end{array}$ & $\begin{array}{l}\text { Analisis } \\
\text { regresi } \\
\text { linier } \\
\text { berganda }\end{array}$ & $\begin{array}{l}\text { Hasil penelitian } \\
\text { menunjukkan bahwa } \\
\text { secara Parsial } \\
\text { Kompensasi } \\
\text { berpengaruh positif } \\
\text { dan signifikan terhadap } \\
\text { Kinerja Karyawan, } \\
\text { Disiplin Kerja } \\
\text { berpengaruh positif } \\
\text { dan signifikan terhadap } \\
\text { Kinerja Karyawan.Dan } \\
\text { secara Simultan } \\
\text { Kompensasi dan } \\
\text { disiplin kerja } \\
\text { berpengaruh positif } \\
\text { dan signifikan terhadap } \\
\text { Kinerja Karyawan. }\end{array}$ \\
\hline $\begin{array}{l}\text { Erma Safitri } \\
(2013)\end{array}$ & $\begin{array}{l}\text { Pengaruh } \\
\text { Pelatihan Dan } \\
\text { Displin Kerja } \\
\text { Terhadap Kinerja } \\
\text { Karyawan Pada } \\
\text { PT. Angkasa Pura } \\
1 \text { (Persero) } \\
\text { Cabang Bandar } \\
\text { Udara } \\
\text { Internasional } \\
\text { juanda-surabya }\end{array}$ & $\begin{array}{l}\text { analisis } \\
\text { regresi } \\
\text { linier } \\
\text { berganda. }\end{array}$ & $\begin{array}{l}\text { Pelatihan dan displin } \\
\text { kerja secara simultan } \\
\text { berpengaruh postif } \\
\text { terhadap kinerja } \\
\text { karyawan }\end{array}$ \\
\hline $\begin{array}{l}\text { Ilham Thaief } \\
\text { Aris } \\
\text { Baharuddin, } \\
\text { Priyono \& } \\
\text { Mohamad } \\
\text { Syafi'I Idrus } \\
(2015)\end{array}$ & $\begin{array}{l}\text { Effect Of } \\
\text { Training, } \\
\text { Compensation } \\
\text { And Work } \\
\text { Discipline } \\
\text { Against } \\
\text { Employee Job } \\
\text { Performance }\end{array}$ & $\begin{array}{l}\text { Analisis } \\
\text { Regresi } \\
\text { Linier }\end{array}$ & $\begin{array}{l}\text { The training, } \\
\text { compensation and } \\
\text { work discipline } \\
\text { simultaneously and } \\
\text { partially have } \\
\text { significant effects } \\
\text { toward the employee } \\
\text { work performance in } \\
\text { PT. PLN (Persero) } \\
\text { Malang Service and } \\
\text { Network } \\
\text { Area. }\end{array}$ \\
\hline $\begin{array}{l}\text { Leonando } \\
\text { Agusta dan } \\
\text { EddyMadiono } \\
\text { Sutanto } \\
(2013) \\
\end{array}$ & $\begin{array}{l}\text { Pengaruh } \\
\text { Pelatihan Dan } \\
\text { Motivasi Kerja } \\
\text { Terhadap Kinerja } \\
\text { Karyawan Cv } \\
\end{array}$ & $\begin{array}{l}\text { Analisis } \\
\text { Regresi } \\
\text { Linier }\end{array}$ & $\begin{array}{l}\text { Pelatihan }(\mathrm{X} 1) \text { dan } \\
\text { motivasi kerja }(\mathrm{X} 2) \\
\text { berpengaruh positif } \\
\text { dan signifikan terhadap } \\
\text { kinerja karyawan }(\mathrm{Y})\end{array}$ \\
\hline
\end{tabular}




\begin{tabular}{|c|c|c|c|}
\hline & $\begin{array}{l}\text { Haragon } \\
\text { Surabaya }\end{array}$ & & $\begin{array}{l}\text { pada CV Haragon } \\
\text { Surabaya. }\end{array}$ \\
\hline $\begin{array}{l}\text { Lia Riantika } \\
\text { Tanujaya } \\
(2015)\end{array}$ & $\begin{array}{l}\text { Pengaruh } \\
\text { Pelatihan Kerja } \\
\text { dan Motivasi } \\
\text { Kerja pada } \\
\text { Kinerja } \\
\text { Karyawan } \\
\text { Departemen } \\
\text { Produksi PT } \\
\text { Cornet Crown }\end{array}$ & $\begin{array}{l}\text { Analisis } \\
\text { Regresi } \\
\text { Linier }\end{array}$ & $\begin{array}{l}\text { Hasil penelitian } \\
\text { menunjukkan bahwa } \\
\text { pelatihan kerja } \\
\text { berpengaruh positif } \\
\text { dan signifikan pada } \\
\text { kinerja karyawan dan } \\
\text { motivasi kerja } \\
\text { berpengaruh positif } \\
\text { dan signifikan pada } \\
\text { kinerja karyawan }\end{array}$ \\
\hline $\begin{array}{l}\text { Iwan Kurnia } \\
\text { Wijaya (2018) }\end{array}$ & $\begin{array}{l}\text { Pengaruh } \\
\text { Kepuasan Kerja } \\
\text { Terhadap Kinerja } \\
\text { Karyawan } \\
\text { Cv Bukit } \\
\text { Sanomas }\end{array}$ & $\begin{array}{l}\text { Analisis } \\
\text { Regresi } \\
\text { Linier } \\
\text { Sederhana }\end{array}$ & $\begin{array}{l}\text { Menurut hasil analisis } \\
\text { dan pembahasan yang } \\
\text { telah dilakukan, maka } \\
\text { ditarik kesimpulan } \\
\text { dalam penelitian ini } \\
\text { adalah ditemukan } \\
\text { bahwa kepuasan kerja } \\
\text { karyawan CV Bukit } \\
\text { Sanomas memiliki } \\
\text { pengaruh terhadap } \\
\text { kinerja karyawan. }\end{array}$ \\
\hline $\begin{array}{l}\text { Garry Surya } \\
\text { Changgriawan } \\
(2017)\end{array}$ & $\begin{array}{l}\text { Pengaruh } \\
\text { Kepuasan Kerja } \\
\text { Dan Motivasi } \\
\text { Kerja Terhadap } \\
\text { Kinerja Kinerja } \\
\text { Karyawan Di One } \\
\text { Way Production }\end{array}$ & $\begin{array}{l}\text { Regresi } \\
\text { Linier } \\
\text { Berganda } \\
\text { Dengan } \\
\text { Disertai Uji } \\
\text { F } \\
\text { (Simultan) } \\
\text { Dan Uji T } \\
\text { (Parsial). }\end{array}$ & $\begin{array}{l}\text { Hasil Penelitian } \\
\text { Menunjukkan Bahwa } \\
\text { Kepuasan Kerja } \\
\text { Berpengaruh Terhadap } \\
\text { Kinerja Karyawan Dan } \\
\text { Motivasi Tidak } \\
\text { Berpengaruh Terhadap } \\
\text { Kinerja Karyawan }\end{array}$ \\
\hline $\begin{array}{l}\text { Mr. Abdul } \\
\text { Hameed, } \\
\text { Mphil, } \\
\text { Muhammad } \\
\text { Ramzan, } \\
\text { MBA, Hafiz } \\
\text { M. Kashif } \\
\text { Zubair, MBA, } \\
\text { Muhammad } \\
\text { Arslan, MBA } \\
\text { 2014 }\end{array}$ & $\begin{array}{l}\text { Impact Of } \\
\text { Compensation On } \\
\text { Employee } \\
\text { Performance } \\
\text { (Empirical } \\
\text { Evidence From } \\
\text { Banking Sector } \\
\text { Of Pakistan) }\end{array}$ & $\begin{array}{l}\text { Analisi } \\
\text { regresi } \\
\text { linier }\end{array}$ & $\begin{array}{l}\text { It is concluded from } \\
\text { different results that } \\
\text { compensation has } \\
\text { positive impact on } \\
\text { employee performance. }\end{array}$ \\
\hline
\end{tabular}




\begin{tabular}{|l|l|l|l|}
\hline Risha Faiq & Pengaruh & Analisi & Kompensasi Dan \\
Fakhri (2015) & Kompensasi Dan & regresi & Pelatihan Kerja \\
& Pelatihan Kerja & linier & Berpengaruh Positif \\
& Terhadap Kinerja & & Terhadap Kinerja \\
& Karyawan & & Karyawan, Variable \\
& Dengan & & Kepuasan Kerja \\
& Kepuasan Kerja & & Memoderasi \\
& Sebagi Variable & & Kompensasi Dan \\
& Intervening(Studi & & Pelatihan Kerja \\
& Pada PT. Audio & & Terhadap Kinerja \\
& Sumitomo & & Karyawan \\
& Technology & & \\
& (AST) Indonesia) & & \\
\hline
\end{tabular}

\subsection{Kerangka Teoritik}

\section{Gambar Kerangka Teoritik}

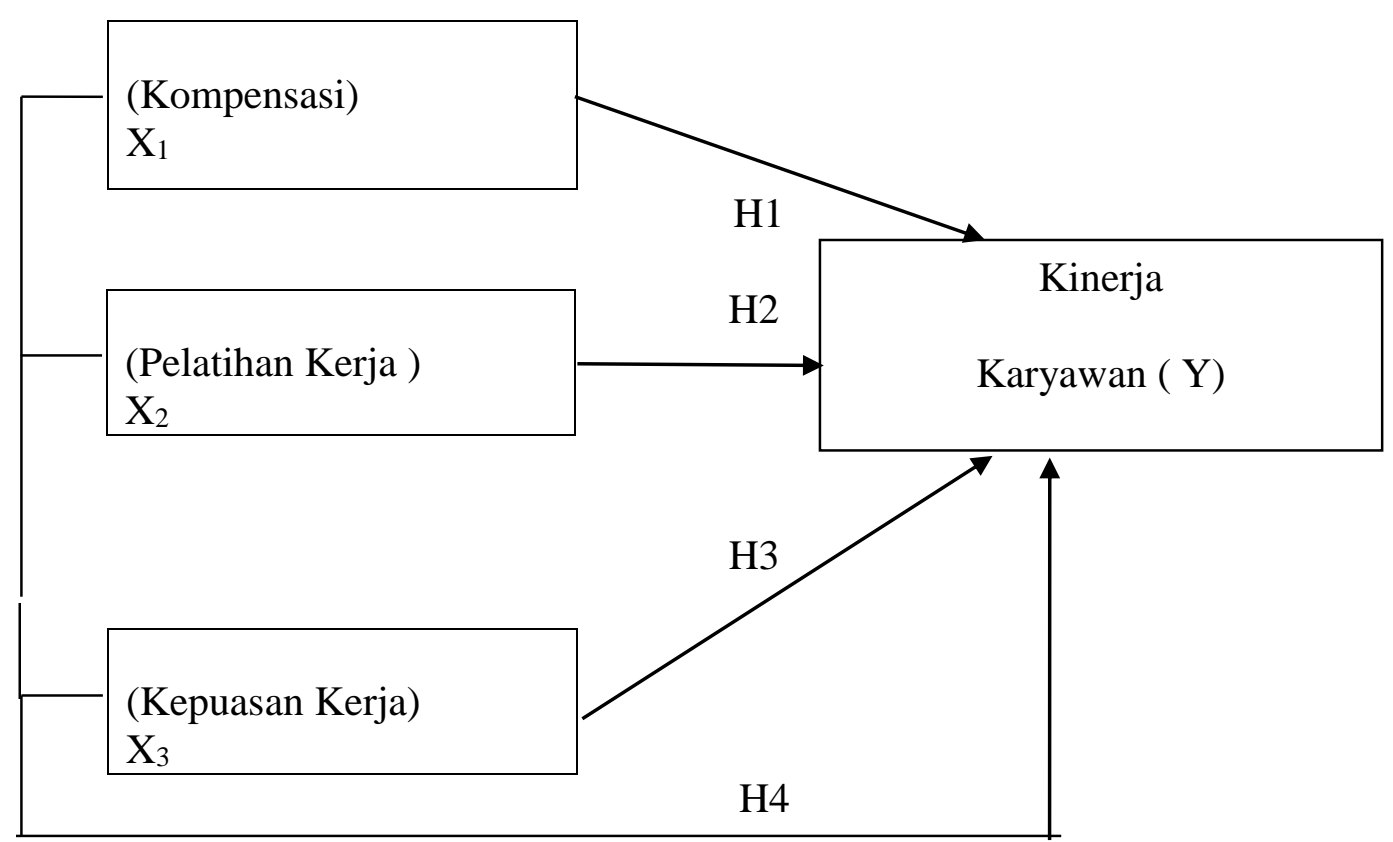

Keterangan :

X1 : Variabel pengaruh (pelatihan)

X2 : Variabel pengaruh (pelatihan kerja)

X3 : Variabel pengaruh (kepuasan kerja )

Y : Variabel terpengaruhi (kinerja karyawan)

: Menunjukkan pengaruh variabel terhadap variabel terpengaruhi 


\subsection{Definisi Operasional Variabel}

\begin{tabular}{|c|c|c|c|c|}
\hline Variabel & Definisi & Indikator & Alat Ukur & Skala \\
\hline $\begin{array}{l}\text { Kompensas } \\
\text { i } \\
\text { (X1) }\end{array}$ & $\begin{array}{l}\text { Kompensasi } \\
\text { adalah semua } \\
\text { imbalan yang } \\
\text { diterima oleh } \\
\text { seorang pekerja } \\
\text { atas jasa atau } \\
\text { hasil kerjanya } \\
\text { pada sebuah } \\
\text { organisasi atau } \\
\text { perusahaan } \\
\text { dimana imbalan } \\
\text { tersebut dapat } \\
\text { berupa uang } \\
\text { ataupun barang, } \\
\text { baik langsung } \\
\text { ataupun tidak } \\
\text { langsung. }\end{array}$ & $\begin{array}{l}\text { Menurut } \\
\text { Atmajawati } \\
(2007: 21) \text { indikator } \\
\text { Kompensasi terdiri } \\
\text { atas : } \\
\text { 1. Gaji. } \\
\text { 2. Insentif } \\
\text { 3. Tunjangan }\end{array}$ & Kuesioner & Ordinal \\
\hline $\begin{array}{l}\text { Pelatihan } \\
\text { Kerja } \\
(\mathrm{X} 2)\end{array}$ & $\begin{array}{l}\text { pelatihan kerja } \\
\text { merupakan } \\
\text { proses } \\
\text { pendidikan } \\
\text { dalam jangka } \\
\text { pendek dengan } \\
\text { tujuan untuk } \\
\text { memenuhi } \\
\text { kebutuhan } \\
\text { organisasi dan } \\
\text { mencapai tujuan } \\
\text { organisasi. }\end{array}$ & $\begin{array}{l}\text { Rivai dan Sagala } \\
\text { (2013, p. 226) } \\
\text { menyebutkan } \\
\text { beberapa indikator } \\
\text { pelatihan meliputi: } \\
\text { 1. kualitas materi } \\
\text { pelatihan } \\
\text { 2. kualitas metode } \\
\text { pelatihan } \\
\text { 3. kualitas } \\
\text { instruktur } \\
\text { pelatihan, } \\
\text { 4. kualitas sarana } \\
\text { dan fasilitas } \\
\text { pelatihan } \\
\text { 5. kualitas peserta } \\
\text { pelatihan }\end{array}$ & Kuesioner & Ordinal \\
\hline
\end{tabular}




\begin{tabular}{|c|c|c|c|c|}
\hline $\begin{array}{l}\text { Kepuasan } \\
\text { Kerja } \\
\text { (X3) }\end{array}$ & $\begin{array}{l}\text { kepuasan kerja } \\
\text { yaitu tingkat } \\
\text { kesenangan } \\
\text { yang dirasakan } \\
\text { seseorang atas } \\
\text { peranan atau } \\
\text { pekerjaanya } \\
\text { dalam } \\
\text { organisasi. }\end{array}$ & $\begin{array}{l}\text { Robbins } \\
\text { (2010:149) lima } \\
\text { indikator yang } \\
\text { dapat menjadi tolak } \\
\text { ukur kepuasan } \\
\text { kerja, antara lain: } \\
\text { 1. Kepuasan } \\
\text { dengan gaji } \\
\text { 2. Kepuasan } \\
\text { dengan } \\
\text { promosi } \\
\text { 3. Kepuasan } \\
\text { dengan rekan } \\
\text { kerja } \\
\text { 4. Kepuasan } \\
\text { dengan } \\
\text { atasan } \\
\text { 5. Kepuasan } \\
\text { dengan pekerjaan } \\
\text { itu sendiri }\end{array}$ & Kuesioner & Ordinal \\
\hline $\begin{array}{l}\text { Kinerja } \\
\text { Karyawan } \\
\text { (Y) }\end{array}$ & $\begin{array}{l}\text { Kinerja adalah } \\
\text { hasil atau } \\
\text { tingkat } \\
\text { keberhasilan } \\
\text { seseorang } \\
\text { secara } \\
\text { keseleruhan } \\
\text { selama periode } \\
\text { tertentu di } \\
\text { dalam } \\
\text { melaksanakan } \\
\text { tugas seperti } \\
\text { target atau } \\
\text { sasaran, standar } \\
\text { hasil kerja yang } \\
\text { telah disepakati } \\
\text { bersama. }\end{array}$ & $\begin{array}{l}\text { (Robbins 2006): } \\
\text { 1) Kualitas } \\
\text { 2) Kuantitas } \\
\text { 3) Ketepatan } \\
\text { Waktu } \\
\text { 4) Efektivitas } \\
\text { 5) Kemandirian }\end{array}$ & Kuesioner & Ordinal \\
\hline
\end{tabular}

Adapun kuesioner yang digunakan dalam penelitian ini dirujukan daeri:

$\begin{array}{ll}\text { Variabel } X_{1} \text { Kompensasi } & \text { : Dea Putri Rhizenda } \\ \text { Variable } X_{2} \text { Pelatihan Kerja } & \text { : Chrizant Tia Tira Manafe } \\ \text { Variable } X_{3} \text { Kepuasan Kerja } & \text { :Edwin Hargono } \\ \text { Variable Y Kinerja Karywan } & \text { : Mailul Hashfi }\end{array}$




\subsection{Hipotesis}

Menurut Sugiyono (2014:134) hipotesis merupakan jawaban sementara terhadap rumusan masalah penelitian, dimana rumusan masalah penelitian telah dinyatakan dalam bentuk kalimat pertanyaan.

Berdasarkan latar belakang dan landasan teori, perumusan masalah serta penelitian terdahulu, maka penulis mengajukan hipotesis yang merupakan kesimpulan sementara bagaimana tiga variabel bebas terhadap satu variabel terikat dalam penulisan hipotesis ini sebagai berikut:

H1 = Diduga Kompensasi berpengaruh terhadap kinerja karyawan marketing pada PT Agung Toyota Bengkulu.

H2 = Diduga Pelatihan kerja berpengaruh terhadap kinerja karyawan marketing pada PT Agung Toyota Bengkulu.

H3 = Diduga Kepuasan Kerja berpengaruh terhadap kinerja karyawan marketing pada PT Agung Toyota Bengkulu.

H4 = Diduga Kompensasi, Pelatihan Kerja Dan Kepuasan Kerja Berpengaruh Terhadap Kinerja Karyawan Marketing Pada Pt Agung Toyota Bengkulu. 


\section{BAB III \\ METODE PENELITIAN}

\subsection{Tempat dan Waktu Penelitian}

Penelitian ini dilaksanakan di PT. Agung Toyota Bengkulu. Waktu penelitian pada bulan Januari dari tanggal 18 januari-28 januari tahun 2020 sampai dengan selelesai

\subsection{Metode Penelitian}

Jenis penelitian ini dikategorikan sebagai explanatory research yaitu penelitian yang bertujuan menjelaskan hubungan kausal antara variabel-variabel melalui pengujian hipotesis. Metode penelitian yang akan dilakukan ialah penelitian kuantitatif.

Menurut Sugiyono (2010:13) metode penelitian kuantitatif dapat diartikan sebagai "metode penelitian yang berlandaskan pada filsafat positivisme, digunakan untuk meneliti pada populasi atau sampel tertentu, teknik pengambilan sampel pada umumnya dilakukan secara acak, pengumpulan data menggunakan instrumen penelitian, analisis data bersifat kuantitatif/statistik dengan tujuan untuk menguji hipotesis yang telah ditetapkan. Penelitian ini menganalisis pengaruh Kompensasi, Pelatihan Kerja Dan Kepuasan Kerja Terhadap Kinerja Karyawan Marketing pada PT. Agung Toyota Bengkulu.

\subsection{Populasi dan Sampel}

Populasi dalam penenlitian ini adalah karyawan pada PT. Agung Toyota Bengkulu yang berjumlah 97 karyawan marketing. Populasi adalah wilayah generalisasi yang terdiri atas obyek atau subyek yang mempunyai kualitas dan karakteristik tertentu yang ditetapkan oleh peneliti untuk dipelajari kemudian ditarik kesimpulannya (Sugiyono, 2012,p. 80) 
Penelitian ini menggunakan seluruh anggota populasinya disebut sampel total (total sampling) atau sensus. Penggunaan metode ini berlaku jika anggota populasi relatif kecil (mudah dijangkau). Dalam penelitian ini, karena jumlah relatif kecil dan relative mudah dijangkau, maka penulis menggunakan metode total sampling. Dengan metode pengambilan sampel ini diharapkan hasilnya dapat cenderung lebih mendekati nilai sesungguhnya dan diharapkan dapat diperkecil pula terjadinya kesalahan atau penyimpangan terhadap nilai populasi( Usman dan Akbar, 2008)

\subsection{Teknik Pengumpulan Data}

Pengumpulan data dalam kegiatan penelitian sangatlah penting karena berkaitan dengan tersedianya data yang dibutuhkan untuk menjawab permasalahan dalam penelitian, sehingga kesimpulan yang diambil adalah benar. Oleh karena itu, penelitian metode pengumpulan data harus dilakukan dengan tepat.

\section{Observasi}

Observasi merupakan suatu teknik atau cara pengumpulan data dengan jalan mengadakan pengamatan terhadap kegiatan yang sedang berlangsung. Adapun jenis observasi yang peneliti gunakan untuk mendapatkan data yang diperlukan guna mengetahui tujuan penelitian ini adalah observasi aktifitas kerja karyawan.

2. Wawancara

Wawancara merupakan peretemuan dua orang untuk bertukar informasi dan ide melalui Tanya jawab, sehingga dapat dikontruksikan makna dalam suatu topic tertentu (Sugiyono, 2012). Wawancara dilakukan dengan pimpinan dan karyawan PT Agung Toyota Bengkulu. 
3. Kuesioner

Kuesioner merupakan teknik pengumpulan data yang dilakukan dengan cara member seperangkat pertanyaan atau pernyataan tertulis kepada responden untuk dijawabnya (Sugiyono, 012). Kuesioner pada penelitian ini terdiri dari karakteristik responden, pernyataan pada Variabel Kompensasi, Pelatihan Kerja, dan Kepuasan Kerja serta pernyataan pada variable kinerja.

Penelitian ini menggunakan skala ordinal, menurut Sugiyono (2014:98) menyatakan skala ordinal sebagai berikut : "skala ordinal adalah skala pengukuran yang tidak hanya menyatakan kategori, tetapi juga menyatakan peringkat construct yang diukur”. Dimana setiap pertanyaan mempunyai 5 opsi sebagai berikut.

Tabel 3.1

Skala Ordinal

\begin{tabular}{|l|l|l|}
\hline No & Pernyataan & Bobot \\
\hline 1 & Sangat Setuju (SS) & 5 \\
\hline 2 & Setuju (S) & 4 \\
\hline 3 & Normal (N) & 3 \\
\hline 4 & Tidak Setuju (TS) & 2 \\
\hline 5 & Sangat Tidak Setuju(STS) & 1 \\
\hline
\end{tabular}

Tabel 3.2

Kisi-Kisi Kuesioner

\begin{tabular}{|c|c|c|c|c|}
\hline No & Variabel & Indikator & Butir & $\sum$ \\
\hline 1 & $\begin{array}{l}\text { Kinerja Karyawan } \\
\text { (Y) }\end{array}$ & $\begin{array}{l}\text {-Kualitas } \\
\text {-Kuantitas } \\
\text {-Ketepatan } \\
\text { Waktu } \\
\text {-Efektivitas } \\
\text {-Kemandirian }\end{array}$ & $\begin{array}{l}1-2 \\
3-4 \\
5-6 \\
7-8 \\
9-10\end{array}$ & $\begin{array}{l}2 \\
2 \\
2 \\
2 \\
2\end{array}$ \\
\hline & & & Jumlah & 10 \\
\hline 2 & $\begin{array}{l}\text { Kompensasi } \\
\text { (X1) }\end{array}$ & $\begin{array}{l}\text {-Gaji } \\
\text {-Insentif } \\
\text {-Tunjangan }\end{array}$ & $\begin{array}{l}11-12 \\
13-14 \\
15-16\end{array}$ & $\begin{array}{l}2 \\
2\end{array}$ \\
\hline
\end{tabular}




\begin{tabular}{|c|c|c|c|c|}
\hline & & & & 2 \\
\hline & & & Jumlah & 6 \\
\hline \multirow[t]{2}{*}{3} & $\begin{array}{l}\text { Pelatihan Kerja } \\
\text { (X2) }\end{array}$ & $\begin{array}{l}\text {-Kualitas } \\
\text { Materi } \\
\text { Pelatihan } \\
\text {-Kualitas } \\
\text { Metode } \\
\text { Pelatihan } \\
\text {-Kualitas } \\
\text { Instruktur } \\
\text { Pelatihan } \\
\text {-Kualitas } \\
\text { Sarana dan } \\
\text { Prasarana } \\
\text { Pelatihan } \\
\text {-Kualitas } \\
\text { Peserta } \\
\text { Pelatiahan }\end{array}$ & $\begin{array}{l}17-18 \\
19-20 \\
21-22 \\
23-24 \\
25-26\end{array}$ & 2 \\
\hline & & & Jumlah & 10 \\
\hline 4 & $\begin{array}{l}\text { Kepuasan Kerja } \\
\text { (X3) }\end{array}$ & $\begin{array}{l}\text {-Kepuasan } \\
\text { dengan Gaji } \\
\text {-Kepuasan } \\
\text { dengan } \\
\text { Promosi } \\
\text {-Kepuasan } \\
\text { dengan } \\
\text { Rekan Kerja } \\
\text {-Kepuasan } \\
\text { dengan } \\
\text { Atasan } \\
\text {-Kepuasan } \\
\text { dengan } \\
\text { pekerjaan itu } \\
\text { sendiri }\end{array}$ & $\begin{array}{l}31-32 \\
33-34 \\
35-36\end{array}$ & 2 \\
\hline & & & Jumlah & 10 \\
\hline
\end{tabular}

\subsection{Uji Instrumen Penelitian}


Pengujian instrumen penelitian ini yaitu menguji validitas dan realibelitas instrumen.Penggunaan metode pengumpulan data dengan kuisioner, maka kesungguhan responden mengisi merupakan hal yang penting. Adapun uji instrument yang dimaksud adalah menguji valid dan reliabelitas yang dilakukan pada sampel uji, ditentukan dengan sampel khusus sejumlah 20 orang responden diluar sampel penelitian yaitu karyawan PT Kangaroo Motor Mandiri (Suzuki) instrument yang valid dan reliabel merupakan syarat mutlak untuk mendapatkan hasil penelitian yang diharapkan. Data yang telah terkumpul diuji dengan menggunakan bantuan program SPSS.

\subsubsection{Uji Validitas Data}

Uji validitas dilakukan untuk mengetahui apakah suatu instrument alat ukur telah menjalankan fungsi ukurnya. Menurut Sekaran (2003) dalam Wijaya (2013:88). Hasil penelitian yang valid bila terdapat kesamaan antara data yang terkumpul dengan data yang sesungguhnya terjadi pada obyek yang di teliti. Instrumen yang valid berarti alat ukur yang digunakan untuk mendapatkan data (mengukur) itu valid. Valid berarti instrument tersebut dapat digunakan untuk mengukur apa yang seharusnya diukur (Sugiyono, 2007:172).

Menurut Sugiyono (2013 : 208) bila koefisien korelasi sama dengan 0,3 atau lebih (paling kecil 0,3),maka butir instrumen dinyatakan valid. Pengujian validitas dalam penelitian ini menggunakan komputer dengan bantuan program SPSS Versi 16.

\subsubsection{Uji Reliabilitas}

Uji reliabilitas adalah alat untuk mengukur suatu kuesioner yang mempunyai indicator dari variable atau konstruk. Uji reliabilitas dapat dilakukan dengan menggunakan bantuan program SPSS 16. Yang akan memberikan fasilitas untuk 
mengukur reliabilitas dengan uji statistic Cronbach Alpha $(\alpha)$. Suatu konstruk atau variable dikatakan reliable jika memberikan nilai Cronbanch Alpha >0,60. Apabila alpha mendekati satu, maka reliabilitas datanya semakin terpercaya (Ghozali,2013).

\subsection{Teknik Analisis Deskriptif}

Bagian analisis ini akan membahas mengenai bentuk tanggapan responden terhadap kuesioner yang disebarkan kepada responden. Dari sebaran jawaban responden selanjutnya akan diperoleh satu kecenderungan jawaban responden terhadap jawaban masing-masing variabel akan didasarkan pada nilai rata-rata skor yang selanjutnya akan dikonfirmasikan pada tabel interval penelitian, adapun perhitungan rata-rata dari responden menggunakan rumus sebagai berikut :

$$
\mathrm{X}=\frac{\sum x}{N}
$$

Keterangan

$$
\begin{aligned}
& \mathrm{X}=\text { angka rata-rata } \\
& \mathrm{N}=\text { jumlah skor } \\
& \sum \mathrm{x}=\text { nilai responden }
\end{aligned}
$$

Hasil rata-rata jawaban responden tersebut dikonfirmasikan pada interval penelitian menetapkan rentang interval penelitian tersebut. Dihitung berdasarkan rumus sebagai berikut :

$$
\mathrm{I}=\frac{R}{K}
$$

Keterangan :

$\mathrm{I}=$ interval

$\mathrm{R}=$ range (nilai tertinggi-nilai terendah)

$$
\mathrm{K}=\text { jumlah kategori }
$$




$$
=\frac{5-1}{5}=0.8
$$

Setelah besarnya interval diketahui, kemudian dibuat rentang skala hingga dapat ditentukan kriteria penelitian persepsi responden terhadap variabel-variabel penelitian sebagai berikut :

Interval penelitian variabel penelitian

Tabel 3.6

Tanggapan Responden Terhadap Variabel

\begin{tabular}{|l|l|}
\hline Interval koefisien & Rata-rata jawaban responden \\
\hline $4,20-5,00$ & Sangat Baik \\
$3,40-4,19$ & Baik \\
$2,60-3,39$ & Cukup Baik \\
$1,80-2,59$ & Tidak Baik \\
$1,00-1,79$ & Sangat tidak Baik \\
\hline
\end{tabular}

Sumber : (Cooper dan Emory, 2016)

\subsection{Uji Asumsi Klasik}

Mengingat data penelitian yang digunakan adalah sekunder, maka untuk memenuhi syarat yang ditentukan sebelum uji hipotesis melalui uji t dan uji F maka perlu dilakukan pengujian atas beberapa asumsi klasik yang digunakan yaitu normalitas, mulltikolinieritas, dan heteroskedastisitas yang secara rinci dapat dijelaskan sebagai berikut:

\subsubsection{Uji Normalitas Data}

Uji normalitas bertujuan untuk menguji apakah dalam model regresi, variable pengganggu atau residual memiliki distribusi normal. Seperti diketahui bahwa uji t dan $\mathrm{f}$ mengasumsikan bahwa nilai residual mengikuti distribusi normal. Ada dua cara untuk mendeteksi apakah residual berdistribusi normal atau tidak yaitu analisis grafik dan uji statistic (Ghozali, 2016). Pengujian normalitas yang digunakan dalam penelitian ini adalah dengan uji kolmogorov-smirnov. Apabila data hasil perhitungan one-simple 
kolmogrov-smirnov menghasilkan nilai diatas 0,05 maka model regresi memenuhi asumsi normalitas. Sebaliknya, apabila data hasil perhitungan one-simple kolmogorov-smirnov menghasilkan nilai dibawah 0,05 maka model regresi tidak memenuhi asumsi normalitas (Ghozali,2016)

\subsubsection{Uji Multikolinieritas}

Uji multikolonieritas bertujuan untuk menguji apakah model regresi ditemukan adanya korelasi antar variable bebas (independen).model regresi yang baik seharusnya tidak terjadi korelasi di antara variable independen. Jika variable independen saling berkorelasi, maka variable-variabel ini tidak orthogonal. Variable orthogonal adalah variable independen yang nilai korelasi antar sesame variable independen sama dengan nol (Ghozali,2016). Dalam penelitian ini, multikolonieritas dapat dilihat dari nilai tolerance dan lawannya variance inflation factor $(V I F)$. Nilai cutoff yang umum dipakai untuk menunjukkan adanya multikolonieritas adlah nilai Tolerance $\leq 0,10$ atau sama dengan nilai VIF $\geq 10$ (Ghozali,2016).

\subsubsection{Uji Heterokedastisitas}

Uji heteroskedastisitas bertujuan untuk menguji apakah dalam model regresi terjadi ketidaksamaan variance dari residual satu pengamatan ke pengamatan yang lain. Jika variance dari residual satu pengamatan ke pengamatan lain tetap, maka disebut Homokedastisitas dan jika berbeda disebut heteroskedastisitas. Model regresi yang baik adalah yang Homokedastisitas atau tidak terjadi heteroskedastisitas. (Ghozali, 2016).

\subsection{Analisis Regresi Linier Berganda}

Mengacu pada tujuan dan hipotesis penelitian, maka model analisis yang digunakan adalah analisis regresi linier berganda. Penggunaan analisis ini dengan alasan untuk mengetahui hubungan antara variabel bebas dengan variabel terikat, yaitu antara 
Kompensasi $\left(\mathrm{X}_{1}\right)$, Pelatihan Kerja $\left(\mathrm{X}_{2}\right)$ Kepuasan Kerja $\left(\mathrm{X}_{3}\right)$ terhadap Kinerja Karyawan (Y). Menurut Sugiyono (2009), persamaan analisis regresi linier berganda dapat dirumuskan sebagai berikut:

$$
\mathrm{Y}=\mathrm{a}+\mathrm{b}_{1} \mathrm{X}_{1}+\mathrm{b}_{2} \mathrm{X}_{2}+\mathrm{b}_{3} \mathrm{X}_{3}+\mathrm{e}
$$

Keterangan :

$\begin{array}{ll}\mathrm{Y} & : \text { Variabel Kinerja } \\ \mathrm{a} & : \text { Constanta } \\ \mathrm{b}_{1} & : \text { Koefisien regresi antara Kompensasi dengan kinerja } \\ \mathrm{b}_{2} & : \text { Koefisien regresi antara Pelatihan Kerja dengan kinerja } \\ \mathrm{b}_{3} & : \text { Koefisien regresi antara Kepuasan kerja dengan kinerja } \\ \mathrm{X} 1 & : \text { Variabel Kompensasi } \\ \mathrm{X} 2 & : \text { Variabel Pelatihan } \\ \mathrm{X} 3 & : \text { Variabel Kepuasan } \\ \mathrm{e} & : \text { Error }\end{array}$

\subsection{Uji Determinasi(R)}

Uji determinasi $\left(\mathrm{R}_{2}\right)$ merupakan alat untuk mengukur beberapa jauh kemampuan model dalam menerangkan variasi variabel dependen. Nilai determinasi adalah antara nol atau satu. Nilai $\mathrm{R}^{2}$ yang kecil berarti kemampuan variabel-variabel independen dalam menjelaskan variasi variabel dependen amat terbatas. Dan sebaliknya jika nilai yang mendekati 1 berarti variabel-variabel independen memberikan hampir semua informasi yang dibutuhkan untuk memperdiksi variabel-variabel dependen Ghozali (2012 : 97).

\subsection{Uji Hipotesis}

Penelitian ini juga mengunakan uji hipotesis. Data diperoleh dari hasil pengumpulan data di atas dapat diperoses sesuai dengan jenis data kemudia disajikan dalam bentu tabel dan aangka metode statistik seagai berikut: 


\subsubsection{Uji t (Uji Parsial)}

Menurut Ghozali (2011) Uji t pada dasarnya digunakan untuk menunjukkan sejauh mana pengaruh satu variabel independen secara persial (individual) dalam menerangkan variabel dependen. Uji t yaitu suatu uji untuk mengetahui signifikan pengaruh variabel bebas (Kompensasi, Pelatihan Kerja dan Kepuasan Kerja ) secara persial atau individu menerangkan pengaruh terhadap variabel terikat Kinerja Karyawan). Pengambilan keputusan yaitu dengan nilai signifikan 0,05 dan membandingkan t hitung dengan t tabel ditentukan sebagai berikut :

1) Apabila $t_{\text {hitung }}>t_{\text {tabel }}$ dan signifikansi $<\alpha(0,05)$, maka Ho ditolak dan Ha diterima yang artinya variabel indevenden secara persial berpengaruh terhadap variabel dependen.

2) Apabila $t_{\text {hitung }}<t_{\text {tabel }}$ dan signifikansi $>\alpha(0,05)$, maka Ho diterima dan Ha ditolak yang artinya variabel independen secara persial tidak berpengaruh terhadap variabel dependen.

\subsubsection{Uji F (Uji Simultan)}

Uji ini bertujuan untuk mengetahui pengaruh semua variabel independen yaitu Kompensasi, Pelatihan Kerja dan Kepuasan Kerja yang terdapat didalam model secara bersama-sama (simultan) terhadap variabel dependen yaitu Kinerja Karyawan. Untuk membuktikan kebenaran hipotesis digunakan uji $\mathrm{F}$, yaitu untuk mengetahui sejauh mana variabel-variabel bebas yang digunakan mampu menjelaskan variabel terikatnya. Apabila dari perhitungan nilai $\mathrm{F}>\mathrm{F}$ tabel pada taraf signifikan 5\%, maka dapat dikatakan bahwa variabel bebas dapat menerangkan variabel terikat secara serentak. Sebaliknya jika nilai $\mathrm{F}<\mathrm{F}$ pada taraf signifikan 5\%, maka dapat dikatakan bahwa variabel bebas tidak mampu menjelaskan variabel terikat 


\section{BAB IV \\ HASIL DAN PEMBAHASAN}

\subsection{Hasil Penelitian}

\subsection{Karakteristik responden}

Responden yang menjadi subjek pada penelitian ini adalah PT Agung Toyota Bengkulu. Dari hasil pengunpulan data melalui koesioner terhadap 97 orang yang dijadikan responden penelitian, maka dapat diketahui karakteristik responden berdasarkan jenis kelamin, usia, dan pendidikan terakhir.

\subsubsection{Karakteristik Responden Berdasarkan usia}

Jumlah responden berdasarkan usia yang ada Pada PT Agung Toyota Bengkulu dapat dilihat pada tabel 4.1

\section{Tabel 4.1}

Karakteristik Responden Berdasarkan Usia

\begin{tabular}{|l|l|l|}
\hline Usia & Frekuensi & Persentase \\
\hline $20-29$ & 46 & $47,4 \%$ \\
\hline $30-39$ & 49 & $50,5 \%$ \\
\hline $40-49$ & 2 & $2,06 \%$ \\
\hline Total & 97 & $100 \%$ \\
\hline
\end{tabular}

Sumber: Data yang diolah 2020

Berdasarkan tabel 4.1 Diketahui karakteristik responden berdasarkan usia yang paling mendominasi usia 30-39 responden dengan persentase 50,5\%. Dari data tersebut menyatakan bahwa Pada PT Agung Toyota Bengkulu yang paling banyak yaitu umur 30-39 karena diumur tersebut dalam mendirikan suatu usaha sudah memiliki pengalaman yang lebih banyak, dan usaha nya sudah lama berdiri 


\subsubsection{Karakteristik Responden Berdasarkan Jenis Kelamin}

Jumlah responden berdasarkan jenis kelamin yang ada pada Pada PT Agung Toyota Bengkulu dapat dilihat pada tabel 4.2

Tabel 4.2

Karakteristik Responden Berdasarkan jenis Kelamin

\begin{tabular}{|l|l|l|}
\hline Jenis Kelamin & Frekuensi & Persentase \\
\hline Laki-laki & 90 & $92,7 \%$ \\
\hline Perempuan & 7 & $7,2 \%$ \\
\hline Total & 97 & $100 \%$ \\
\hline
\end{tabular}

Sumber: Data yang diolah 2020

Berdasarkan tabel di atas diketahui karakteristik responden berdasarakan jenis kelamin laki-laki sebanyak 97 orang responden atau 92,7 \%, kemudian jumlah responden perempuan sebanyak 7 orang responden atau 7,2 \%. Dari data tersebut menyatakan bahwa Pada PT Agung Toyota Bengkulu lebih banyak laki-laki dari perempuan.

\subsubsection{Karakteristik Responden Berdasarkan Pendidikan}

Jumlah responden berdasarkan pendidikan terakhir yang ada pada Pada PT Agung Toyota Bengkulu dapat dilaihat pada tabel 4.3

Tabel 4.3

Karakteristik Responden Berdasarkan tingkat Pendidikan

\begin{tabular}{|l|l|l|}
\hline Pendidikan Terakhir & Frekuensi & Persentase \\
\hline SMA & 13 & $13,4 \%$ \\
\hline DIII & 29 & $29,8 \%$ \\
\hline PERGURUAAN TINGGI & 55 & $56,7 \%$ \\
\hline TOTAL & 97 & 100.0 \\
\hline
\end{tabular}

Sumber: Data yang diolah 2020 
Berdasarkan tabel 4.3 diketahui karakteristik responden berdasarkan pendidikan terakhir yang paling mendominasi SMA sebanyak 13 responden dengan persentase 13,4\%, DIII sebanyak 29 responden dengan presentasi 29,8 \% dan S1 Sebanyak 55 responden dengan presentasi 56,7\%. Dari data tersebut dapat disimpulkan bahwa Pada PT Agung Toyota Bengkulu sudah memiliki pendidikan yang cukup tinggi.

\subsection{Analisis Deskriptif}

\subsubsection{Tanggapan Responden Terhadap Variabel Kompensasi $\left(\mathrm{X}_{1}\right)$}

Pada Variabel Kompensasi penilian dilakukan dengan Tiga Indikator, Adapun Tanggapan responden terhadap variable Kompensasi adalah sebagai berikut :

Tabel 4.4

Tanggapan Responden

Terhadap Variabel Kompensasi $\left(\mathrm{X}_{1}\right)$

\begin{tabular}{|c|c|c|c|c|c|c|c|c|}
\hline \multirow[b]{2}{*}{ No } & \multirow[b]{2}{*}{ Pernyataan } & \multicolumn{5}{|c|}{ Penilaian } & \multirow[b]{2}{*}{ Jumlah } & \multirow{2}{*}{$\begin{array}{l}\text { Rata- } \\
\text { rata }\end{array}$} \\
\hline & & STS & $\mathrm{TS}$ & $\mathrm{N}$ & $S$ & SS & & \\
\hline 1 & $\begin{array}{l}\text { Gaji yang saya } \\
\text { terima sesuai dengan } \\
\text { harapan }\end{array}$ & & 3 & 47 & 35 & 12 & 347 & 3.58 \\
\hline 2 & $\begin{array}{l}\text { Gaji yang diterima } \\
\text { sudah sesuai dengan } \\
\text { pekerjaan }\end{array}$ & & 6 & 35 & 41 & 15 & 356 & 3.67 \\
\hline 3 & $\begin{array}{l}\text { Insentif yang saya } \\
\text { terima sudah sesuai } \\
\text { dengan prestasi kerja } \\
\text { selama ini }\end{array}$ & & 4 & 37 & 37 & 19 & 362 & 3.73 \\
\hline 4 & $\begin{array}{l}\text { insentif yang } \\
\text { diberikan perusahaan } \\
\text { berdasarkan kinerja } \\
\text { karyawan }\end{array}$ & & 1 & 29 & 50 & 17 & 374 & 3.86 \\
\hline 5 & $\begin{array}{l}\text { THR sudah sesuai } \\
\text { harapan }\end{array}$ & & 4 & 36 & 38 & 19 & 363 & 3.74 \\
\hline 6 & $\begin{array}{l}\text { Perusahaan } \\
\text { memberikan asuransi } \\
\text { kesehatan atau }\end{array}$ & & 4 & 28 & 47 & 18 & 370 & 3.81 \\
\hline
\end{tabular}




\begin{tabular}{|l|l|l|l|l|l|l|l|}
\hline $\begin{array}{l}\text { sejenisnya kepada } \\
\text { karyawan }\end{array}$ & & & & & & & \\
\hline Rata-rata
\end{tabular}

Sumber: Data yang diolah 2020

Adapun hasil analisis penilaian responden pada tabel 4.4 Terhadap variabel Kompensasi $\left(\mathrm{X}_{1}\right)$ memiliki nilai rata-rata tertinggi yaitu 3.86 dan memiliki rata-rata terendah yaitu 3,58. Variabel Kompensasi menghasilkan nilai rata-rata sebesar 3.73. Menunjukan bahwa rata-rata pernyataan penilaian responden mengenai variabel Kompensasi adalah pada kategori baik. Dikarenakan pada criteria skor berada pada $(3,40-$ 4,19) di kategorikan baik.

\subsubsection{Tanggapan Responden Terhadap Variabel Pelatihan Kerja $\left(\mathrm{X}_{2}\right)$}

Pada variabel Pelatihan Kerja Penilaian dilakukan dengan Lima Indikator. Adapun tanggapan responden terhadap variabel Pelatihan Kerja adalah sebagai berikut:

Table 4.5

Tanggapan Responden Terhadap Variabel Pelatihan Kerja $\left(\mathrm{X}_{2}\right)$

\begin{tabular}{|c|c|c|c|c|c|c|c|c|}
\hline \multirow[b]{2}{*}{ No } & \multirow[b]{2}{*}{ Pernyataan } & \multicolumn{5}{|c|}{ Penilaian } & \multirow[b]{2}{*}{ Jumlah } & \multirow{2}{*}{$\begin{array}{l}\text { Rata- } \\
\text { rata }\end{array}$} \\
\hline & & STS & TS & $\mathrm{N}$ & $\mathrm{S}$ & SS & & \\
\hline 1 & $\begin{array}{l}\text { Materi pelatihan } \\
\text { sesuai dengan } \\
\text { pekerjaan karyawan }\end{array}$ & & & 22 & 48 & 27 & 393 & 4.05 \\
\hline 2 & $\begin{array}{l}\text { Materi yang } \\
\text { diberikan mudah } \\
\text { dipahami peserta }\end{array}$ & 2 & 3 & 34 & 34 & 24 & 366 & 3.77 \\
\hline 3 & $\begin{array}{l}\text { Metode pelatihan } \\
\text { yang digunakan } \\
\text { terbaru }\end{array}$ & & 4 & 35 & 35 & 23 & 368 & 3.79 \\
\hline 4 & $\begin{array}{l}\text { Metode pelatihan } \\
\text { yang digunakan pada } \\
\text { saat pelatihan } \\
\text { menarik }\end{array}$ & 2 & 4 & 43 & 39 & 9 & 340 & 3.51 \\
\hline
\end{tabular}




\begin{tabular}{|c|c|c|c|c|c|c|c|}
\hline 5 & $\begin{array}{l}\text { Instruktur ahli dalam } \\
\text { menyampaikan } \\
\text { materi saat pelatihan }\end{array}$ & 5 & 35 & 42 & 15 & 358 & 3.69 \\
\hline 6 & $\begin{array}{l}\text { Instruktur } \\
\text { menguasai materi } \\
\text { pelatihan sehingga } \\
\text { mampu menjelaskan } \\
\text { materi dengan baik }\end{array}$ & 3 & 35 & 40 & 19 & 366 & 3.77 \\
\hline 7 & $\begin{array}{l}\text { Saya merasa ruang } \\
\text { aula yang luas bersih } \\
\text { dan terawat dapat } \\
\text { mempermudah } \\
\text { proses pelatihan }\end{array}$ & 1 & 29 & 50 & 17 & 374 & 3.86 \\
\hline 8 & $\begin{array}{l}\text { Saya menggunakan } \\
\text { kursi dan meja } \\
\text { belajar yang baik } \\
\text { sebagai alat } \\
\text { penunjang dalam } \\
\text { pelaksanaan } \\
\text { pelatihan }\end{array}$ & 2 & 27 & 52 & 16 & 373 & 3.85 \\
\hline 9 & $\begin{array}{l}\text { Peserta bersemangat } \\
\text { untuk mengikuti } \\
\text { pelatihan }\end{array}$ & 6 & 31 & 50 & 10 & 355 & 3.66 \\
\hline 10 & $\begin{array}{l}\text { Peserta menguasai } \\
\text { berbagai materi } \\
\text { pelatihan yang } \\
\text { diberikan dengan } \\
\text { cepat }\end{array}$ & 1 & 22 & 48 & 26 & 390 & 4.02 \\
\hline \multicolumn{7}{|c|}{ Rata-rata } & 3.80 \\
\hline
\end{tabular}

Sumber: Data yang diolah 2020

Adapun hasil analisis penilaian responden pada tabel 4.5 Terhadap variabel

Pelatihan Kerja $\left(\mathrm{X}_{2}\right)$ memiliki nilai rata-rata tertinggi yaitu 4.05 dan memiliki rata-rata terendah yaitu 3.51. Variabel Pelatihan Kerja menghasilkan nilai rata-rata sebesar 3.80. Menunjukan bahwa rata-rata pernyataan penilaian responden mengenai variabel Pelatihan Kerja adalah pada kategori baik. Dikarenakan pada criteria skor berada pada $(3,40-4,19)$ di kategorikan baik. 


\subsubsection{Tanggapan Responden Terhadap Kepuasan Kerja (X3)}

Pada variabel Kepuasan Kerja Penilaian dilakukan dengan Lima Indikator. Adapun tanggapan responden terhadap variabel Kepuasan Kerja adalah sebagai berikut:

Tabel 4.6

Tanggapan Responden Terhadap Variabel Kepuasan Kerja $\left(\mathrm{X}_{3}\right)$

\begin{tabular}{|c|c|c|c|c|c|c|c|c|}
\hline \multirow{2}{*}{ No } & \multirow{2}{*}{ Pernyataan } & \multicolumn{5}{|c|}{ Penilaian } & \multirow{2}{*}{ Jumlah } & \multirow{2}{*}{ Rata-rata } \\
\hline & & STS & TS & $\mathrm{N}$ & $S$ & SS & & \\
\hline 1 & $\begin{array}{l}\text { Gaji yang saya } \\
\text { terima seimbang } \\
\text { dengan tugas yang } \\
\text { saya emban }\end{array}$ & & 6 & 38 & 30 & 23 & 361 & 3.72 \\
\hline 2 & $\begin{array}{l}\text { Gaji yang saya } \\
\text { terima berdasarkan } \\
\text { hasil kerja saya }\end{array}$ & & 4 & 27 & 48 & 18 & 371 & 3.82 \\
\hline 3 & $\begin{array}{l}\text { Kesempatan } \\
\text { promosi yang besar } \\
\text { yang diberikan oleh } \\
\text { perusahaan kepada } \\
\text { karyawan }\end{array}$ & & 2 & 27 & 48 & 20 & 377 & 3.89 \\
\hline 4 & $\begin{array}{l}\text { Promosi karyawan } \\
\text { berdasarkan kinerja } \\
\text { yang telah dilakukan }\end{array}$ & & 6 & 35 & 41 & 15 & 356 & 3.67 \\
\hline 5 & $\begin{array}{l}\text { Rekan kerja saya } \\
\text { membantu saya } \\
\text { dalam melakukan } \\
\text { pekerjaan }\end{array}$ & & 4 & 36 & 37 & 20 & 364 & 3.75 \\
\hline 6 & $\begin{array}{l}\text { Saya merasa puas } \\
\text { dengan hubungan } \\
\text { yang harmonis antar } \\
\text { sesama rekan kerja }\end{array}$ & & 6 & 38 & 30 & 23 & 361 & 3.72 \\
\hline 7 & $\begin{array}{l}\text { Saya senang dengan } \\
\text { atasan yang dapat } \\
\text { memberikan } \\
\text { dukungan kepada }\end{array}$ & & 4 & 27 & 48 & 18 & 371 & 3.82 \\
\hline
\end{tabular}




\begin{tabular}{|c|c|c|c|c|c|c|c|c|}
\hline & $\begin{array}{l}\text { karyawan dalam } \\
\text { melaksanakan } \\
\text { pekerjaan }\end{array}$ & & & & & & & \\
\hline 8 & $\begin{array}{l}\text { Kebijakan yang } \\
\text { ditetapkan oleh } \\
\text { pimpinan dapat } \\
\text { meningkatkan } \\
\text { kinerja karyawan }\end{array}$ & & 1 & 23 & 48 & 25 & 388 & 4.00 \\
\hline 9 & $\begin{array}{l}\text { Saya senang } \\
\text { pekerjaan yang } \\
\text { diberikan oleh } \\
\text { perusahaan }\end{array}$ & 2 & 4 & 43 & 39 & 9 & 340 & 3.51 \\
\hline 10 & $\begin{array}{l}\text { Saya senang dengan } \\
\text { pekerjaan saat ini }\end{array}$ & & 2 & 30 & 51 & 14 & 368 & 3.79 \\
\hline \multicolumn{8}{|c|}{ Rata-rata } & 3.77 \\
\hline
\end{tabular}

Sumber: Data yang diolah 2020

Adapun hasil analisis penilaian responden pada tabel 4.6 Terhadap variabel

Kepuasan Kerja $\left(\mathrm{X}_{3}\right)$ memberikan Kepuasan Kerja yang baik untuk Kinerja Karyawan Marketing) memiliki nilai rata-rata tertinggi yaitu 4.00 dan memiliki rata-rata terendah yaitu 3,51. Variabel Kepuasan Kerja menghasilkan nilai rata-rata sebesar 3.77. Menunjukan bahwa rata-rata pernyataan penilaian responden mengenai variabel Kepuasan Kerja adalah pada kategori baik. Dikarenakan pada criteria skor berada pada $(3,40-4,19)$ di kategorikan baik.

\subsubsection{Tanggapan Responden Terhadap Variabel Kinerja Karyawan Marketing} (Y)

Pada variabel Kinerja Karyawan Marketing penilaian dilakukan dengan Lima Indikator. Adapun tanggapan responden terhadap variabel Kinerja Karyawan Marketing adalah sebagai berikut:

Tabel 4.7

Tanggapan Responden

Terhadap Variabel Kinerja Karyawan Marketing (Y) 


\begin{tabular}{|c|c|c|c|c|c|c|c|c|}
\hline \multirow[b]{2}{*}{ No } & \multirow{2}{*}{ Pernyataan } & \multicolumn{5}{|c|}{ Peniliaian } & \multirow[b]{2}{*}{ Jumlah } & \multirow{2}{*}{$\begin{array}{l}\text { Rata- } \\
\text { rata }\end{array}$} \\
\hline & & STS & $\mathrm{TS}$ & $\mathrm{N}$ & $S$ & SS & & \\
\hline 1 & $\begin{array}{l}\text { Karyawan Saya } \\
\text { mampu } \\
\text { menyelesaikan } \\
\text { pekerjaan sesuai } \\
\text { standar yang } \\
\text { ditetapkan } \\
\text { perusahaan. }\end{array}$ & & 6 & 36 & 41 & 14 & 354 & 3.65 \\
\hline 2 & $\begin{array}{l}\text { Karyawan Saya } \\
\text { bekerja melampaui } \\
\text { standar yang } \\
\text { ditetapkan } \\
\text { perusahaan }\end{array}$ & & 4 & 37 & 37 & 19 & 362 & 3.73 \\
\hline 3 & $\begin{array}{l}\text { Karyawan Saya } \\
\text { menyelesaikan tugas } \\
\text { sesuai target yang } \\
\text { ditetapkan } \\
\text { perusahaan }\end{array}$ & & 6 & 39 & 30 & 22 & 359 & 3.70 \\
\hline 4 & $\begin{array}{l}\text { Karyawan Saya } \\
\text { mengerjakan } \\
\text { pekerjaan } \\
\text { melampaui target } \\
\text { yang ditetapkan } \\
\text { perusahaan }\end{array}$ & & 4 & 28 & 48 & 17 & 369 & 3.80 \\
\hline 5 & $\begin{array}{l}\text { Karyawan Saya } \\
\text { datang tepat waktu }\end{array}$ & & 1 & 24 & 47 & 25 & 387 & 3.99 \\
\hline 6 & $\begin{array}{l}\text { Karyawan Saya } \\
\text { tidak pernah absensi } \\
\text { dan bolos saat jam } \\
\text { kerja }\end{array}$ & & 3 & 34 & 36 & 24 & 372 & 3.84 \\
\hline 7 & $\begin{array}{l}\text { Karyawan Saya } \\
\text { mampu } \\
\text { menggunakan } \\
\text { dengan baik fasilitas } \\
\text { dan peralatan yang } \\
\text { diberikan perusahaan } \\
\text { untuk menyelesaikan } \\
\text { pekerjaan }\end{array}$ & & 1 & 30 & 49 & 17 & 373 & 3.85 \\
\hline 8 & $\begin{array}{l}\text { Karyawan Saya } \\
\text { bekerja dengan SOP } \\
\text { (Standar Operasional } \\
\text { Prosedur) }\end{array}$ & 2 & 4 & 35 & 33 & 23 & 362 & 3.73 \\
\hline 9 & $\begin{array}{l}\text { Karyawan Saya } \\
\text { mengerjakan tugas } \\
\text { tanpa harus disuruh } \\
\text { terlebih dahulu }\end{array}$ & 2 & 4 & 44 & 38 & 9 & 339 & 3.49 \\
\hline
\end{tabular}




\begin{tabular}{|l|l|l|l|l|l|l|l|l|}
\hline 10 & $\begin{array}{l}\text { Karyawan Saya } \\
\text { biasa membantu dan } \\
\text { memberikan } \\
\text { motivasi kepada } \\
\text { rekan kerja }\end{array}$ & 2 & 30 & 51 & 14 & 368 & 3.79 \\
\hline Rata-rata & 3.76 \\
\hline
\end{tabular}

Sumber: Data yang diolah 2020

Adapun hasil analisis penilaian responden pada tabel 4.8 Terhadap variabel Kinerja Karyawan Marketing (Y) memiliki rata-rata tertinggi yaitu 3.99, dan indikator kemandirian memiliki rata-rata terendah yaitu 3.49. Dengan variabel kinerja karyawan menghasilkan nilai rata-rata sebesar 3.76. Menunjukan bahwa rata-rata pernyataan penilaian responden mengenai variabel Kinerja Karyawan Marketing adalah pada kategori baik. Dikarenakan pada criteria skor berada pada $(3,40-4,19)$ di kategorikan baik.

\subsection{Uji Instrumen Penelitian}

Pengujian instrumen penelitian ini yaitu menguji validitas dan realibelitas instrumen.Penggunaan metode pengumpulan data dengan kuesioner, maka kesungguhan responden mengisi merupakan hal yang penting. Adapun uji instrument yang dimaksud adalah menguji valid dan reliabelitas yang dilakukan pada sampel uji, ditentukan dengan sampel khusus sejumlah 20 orang responden diluar sampel penelitian yaitu karyawan PT Kangaroo Motor Mandiri (Suzuki) instrument yang valid dan reliabel merupakan syarat mutlak untuk mendapatkan hasil penelitian yang diharapkan. Data yang telah terkumpul diuji dengan menggunakan bantuan program SPSS.

\subsubsection{Uji Validitas Data}

Uji validitas dilakukan untuk mengetahui apakah suatu instrument alat ukur telah menjalankan fungsi ukurnya. Menurut Sekaran (2003) dalam Wijaya (2013:88). Hasil penelitian yang valid bila terdapat kesamaan antara data yang terkumpul dengan data 
yang sesungguhnya terjadi pada obyek yang di teliti. Instrumen yang valid berarti alat ukur yang digunakan untuk mendapatkan data (mengukur) itu valid. Valid berarti instrument tersebut dapat digunakan untuk mengukur apa yang seharusnya diukur (Sugiyono, 2007:172).

Menurut Sugiyono (2013: 208) bila koefisien korelasi sama dengan 0,3 atau lebih (paling kecil 0,3),maka butir instrumen dinyatakan valid. Pengujian validitas dalam penelitian ini menggunakan komputer dengan bantuan program SPSS Versi 16.

Uji validitas pada 20 orang responden karyawan marketing PT. Kangaroo Motor Mandiri (Suzuki). Hasil Pengujian dapat dilihat pada lampiran 3.

Tabel 4.1

Ringkasan Hasil Uji Validitas Variabel Kompensasi, Pelatihan Kerja, Kepuasan Kerja Dan Kinerja Karyawan Marketing

\begin{tabular}{|l|l|l|l|}
\hline Variabel & No Pernyataan & $\begin{array}{l}\text { Total Pearson } \\
\text { Correlation }\end{array}$ & Keterangan \\
\hline & 1 & 0,528 & Valid \\
& 2 & 0,688 & Valid \\
X $_{1}$ & 3 & 0,738 & Valid \\
Kompensasi & 4 & 0,722 & Valid \\
& 5 & 0,782 & Valid \\
& 6 & 0,769 & Valid \\
\hline & 1 & 0,471 & Valid \\
& 2 & 0,715 & Valid \\
& 3 & 0,546 & Valid \\
& 4 & 0,765 & Valid \\
X & 5 & 0,576 & Valid \\
Pelatihan & 6 & 0,769 & Valid \\
kerja & 9 & 0,457 & Valid \\
& 10 & 0,751 & Valid \\
& & 0,613 & Valid \\
\hline
\end{tabular}




\begin{tabular}{|l|l|l|l|}
\hline & 1 & 0,800 & Valid \\
& 2 & 0,508 & Valid \\
& 3 & 0,573 & Valid \\
& 4 & 0,800 & Valid \\
X $_{3}$ & 5 & 0,605 & Valid \\
Kepuasan & 6 & 0,617 & Valid \\
kerja & 7 & 0,487 & Valid \\
& 9 & 0,777 & Valid \\
& 10 & 0,658 & Valid \\
\hline & & 0,800 & Valid \\
& 1 & & \\
Yinerja & 2 & 0,470 & Valid \\
Karyawan & 3 & 0,530 & Valid \\
& 4 & 0,541 & Valid \\
& 7 & 0,542 & Valid \\
& 8 & 0,510 & Valid \\
& 9 & 0,777 & Valid \\
& 10 & 0,645 & Valid \\
& & 0,592 & Valid \\
& & 0,591 & Valid \\
& & 0,530 & Valid \\
\hline
\end{tabular}

\subsubsection{Uji Reliabilitas}

Uji reliabilitas adalah alat untuk mengukur suatu kuesioner yang mempunyai indicator dari variable atau konstruk. Uji reliabilitas dapat dilakukan dengan menggunakan bantuan program SPSS 16. Yang akan memberikan fasilitas untuk mengukur reliabilitas dengan uji statistic Cronbach Alpha $(\alpha)$. Suatu konstruk atau variable dikatakan reliable jika memberikan nilai Cronbanch Alpha >0,60. Apabila alpha mendekati satu, maka reliabilitas datanya semakin terpercaya (Ghozali,2013).

\section{Tabel 4.2}

Ringkasan Hasil Nilai Cronbach Alpa Dari Tiap Variabel

\begin{tabular}{|l|l|l|l|l|}
\hline Variabel & $\begin{array}{l}\text { Nilai Cronbach } \\
\text { Alpa }\end{array}$ & $\begin{array}{l}\text { Cut Of } \\
\text { Value }\end{array}$ & $\begin{array}{l}\text { Jumlah } \\
\text { Pernyataan }\end{array}$ & Keterangan \\
\hline Kompensasi & 0,778 & 0,60 & 6 & Reliabel \\
\hline Pelatihan Kerja & 0,749 & 0,60 & 10 & Reliabel \\
\hline Kepuasan Kerja & 0,762 & 0,60 & 10 & Reliabel \\
\hline Kinerja Karyawan & 0,735 & 0,60 & 10 & Reliabel \\
\hline
\end{tabular}




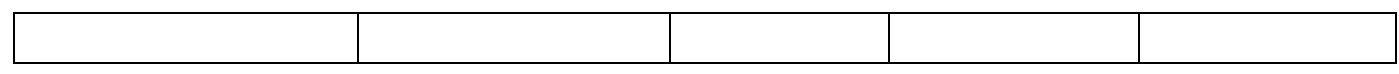

Dari Tabel 3.4 diatas terlihat bahwa semua variable memiliki nilai cronbach alpa lebih besar dari 0,60 maka dapat disimpulkan bahwa semua variable penelitian ini reliabilitas.

\subsection{Uji Asumsi Klasik}

\subsubsection{Uji Asumsi Klasik Normalitas}

Pada tabel uji normalitas dengan mengunakan kolmogorov-smirnov nilai sig > 0,05 bisa dilihat bahwa data berdistribusi normal :

\section{Gambar 4.1}

\section{Grafik Histrogram Uji Normalitas}

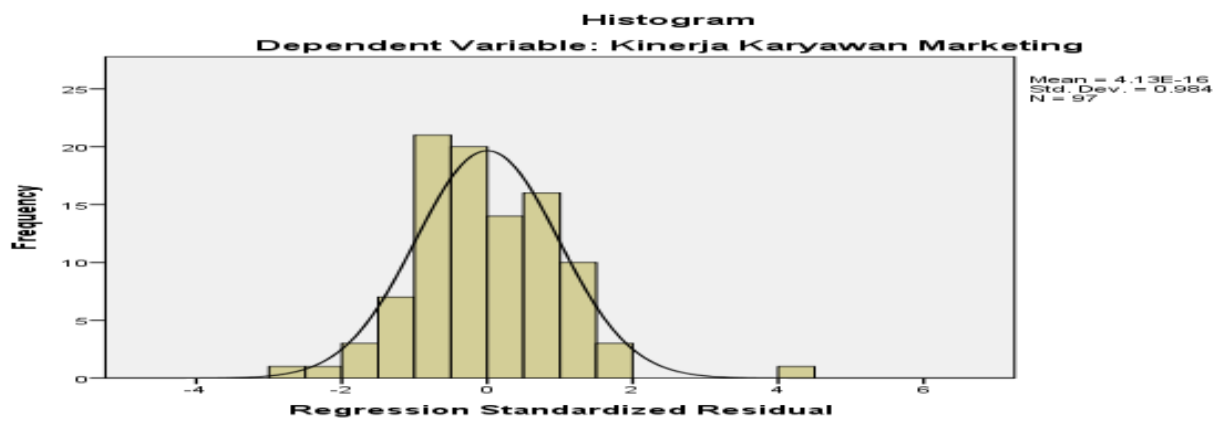

Kompensasi (X1), Pelatihan Kerja (X2) dan Kepuasan Kerja (X3) terhadap Kinerja Karyawan Marketing (Y)

Gambar 4.1 menunjukan bahwa grafik uji normalitas mengambarkan penyebaran data di sekitar garis diagonal dan penyebarannya mengikuti arah garis diagonal grafik tersebut, maka model regresi yang digunakan dalam penelitian ini memenuhi asumsi normalitas. 
Tabel 4.2

Hasil Uji Normalitas

\begin{tabular}{|l|l|l|l|l|l|l|}
\hline \multirow{2}{*}{} & \multicolumn{4}{|l|}{ Kolmogorov-Smirnov ${ }^{\mathrm{a}}$} & \multicolumn{3}{|l|}{ Shapiro-Wilk } \\
\cline { 2 - 7 } & Statistic & Df & Sig. & Statistic & Df & Sig. \\
\hline $\begin{array}{l}\text { Unstandardized } \\
\text { Residual }\end{array}$ & .062 & 95 & .000 & .785 & 95 & .000 \\
\hline
\end{tabular}

Dari hasil uji normalitas diketahui nilai statistik 0,093 atau nilai (siga $=0,062>0,05)$, dapat disimpulkan bahwa residual menyebar normal.

\subsubsection{Uji Asumsi Klasik Multikolinieritas}

Uji multikolinearitas ini bertujuan untuk mengetahui apakah tiap-tiap variabel bebas yaitu Kompensasi, Pelatihan Kerja dan Kepuasan Kerja saling berhubungan secara linear. Pengujian adanya multikolinearitas ini dapat dilakukan dengan melihat nilai toleransi diatas 0,1 dan VIF nya lebih kecil dari 10 tidak ada kecenderungan terjadi gejala multikolinear. Pengujian multikoloneeritas mengunakan software SPSS versi 24 dapat dilihat pada tabel dibawah ini :

Tabel 4.3

Hasil Uji multikolinearitas

\begin{tabular}{|l|l|l|l|l|}
\hline No & Variabel & Tolerance & VIF & Keterangan \\
\hline 1 & Kompensasi & 0.117 & 8.570 & Non Multikolinearitas \\
\hline 2 & Pelatihan Kerja & 0.188 & 5.333 & Non Multikolinearitas \\
\hline 3 & Kepuasan Kerja & 0.238 & 4.204 & Non Multikolinearitas \\
\hline
\end{tabular}

Sumber: Output SPSS 24.0

Berdasarkan tabel 4.3 diatas terlihat bahwa semua variabel mempunyai nilai toleransi diatas 0,1 dan nilai VIF dibawah 10, dengan demikian dapat disimpulkan bahwa variabel pada penelitian ini bebas multikolinearitas. 


\subsubsection{Uji Asumsi Klasik Heterokedasitas}

Uji heterokedasitas bertujuan untuk menguji apakah dalam model regresi terjadi ketidak sama varians. Adapun hasil uji statistic heteroskedastisitas yang diperoleh dalam penelitian ini adalah sebagai berikut outputnya menunjukkan tidak adanya hubungan yang signifikan antara seluruh variabel independent terhadap nilai absolute residual, sehingga dapat disimpulkan bahwa asumsi non-heteroskedastisitas terpenuhi. Dengan gambar sebagai berikut :

\section{Gambar 4.4}

Uji Penyimpangan Heteroskedasitas

Amtara Variabel- Variabel Kompensasi (X1), Pelatihan Kerja (X2) dan Kepuasan Kerja (X3) terhadap Kinerja Karyawan Marketing (Y)

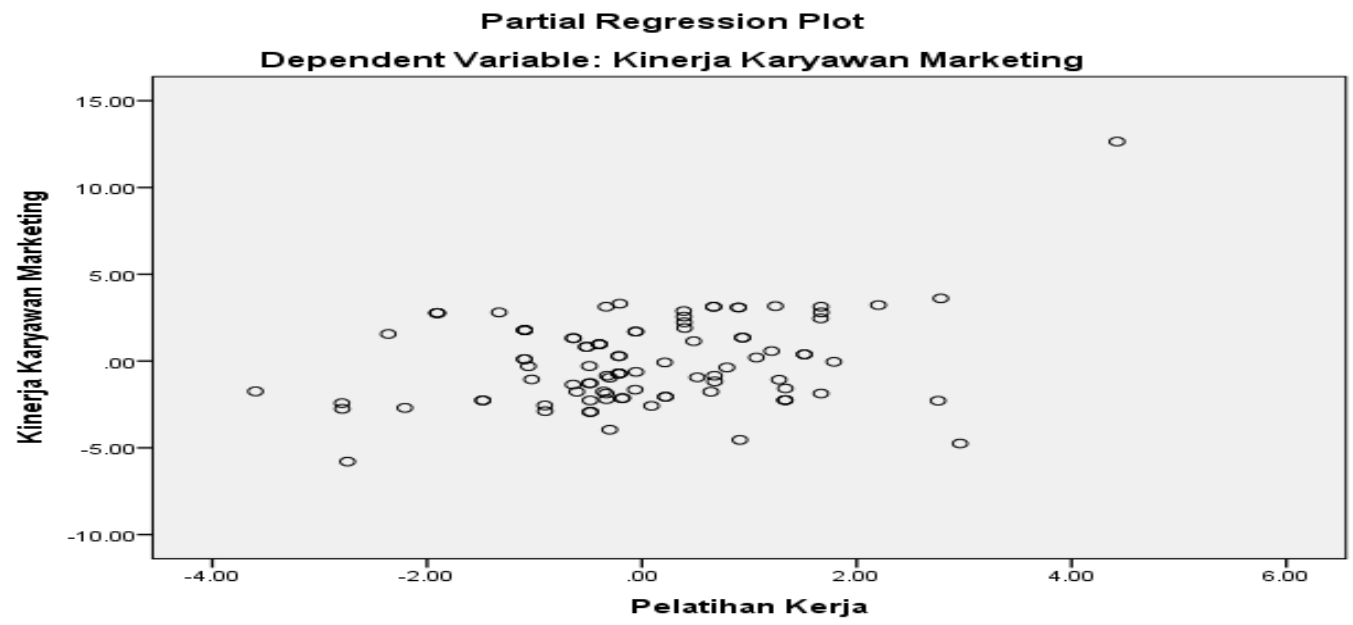

Grafik Scatter Plot yang tampilkan untuk uji Heterokesdastisitas menampakkan titik-titik yang menyebarkan secara acak dan tidak ada pola yang jelas terbentuk serta dalam penyebaran titik-titik tersebut menyebar di bawah dan di atas angka 0 pada sumbu Y. Hal tersebut mengindentifikasikan tidak terjadinya heterokesdastisitas pada model regresi, sehingga model regresi layak dipakai untuk memprediksi variable Kinerja Marketing (Y) 


\subsection{Analisis Regresi Linier Berganda}

Analisis regresi linear berganda yang akan dibahas dalam penelitian ini sehingga penulis bisa menggambarkan mengenai tanggapan responden (Kompensasi, Pelatihan Kerja, Kepuasan Kerja ) terhadap Kinerja Karyawan Marketing pada Pada PT Agung Toyota Bengkulu. Berdasarkan estemasi regresi linier berganda dengan menggunakan program SPSS Versi 24,0 For Windows,maka diperoleh tabel dibawah ini :

Tabel 4.8

Hasil Analisis Regresi Linear Berganda

\begin{tabular}{|c|c|c|c|c|c|c|}
\hline \multicolumn{7}{|c|}{ Coefficients $^{\mathrm{a}}$} \\
\hline \multirow{2}{*}{\multicolumn{2}{|c|}{ Model }} & \multicolumn{2}{|c|}{$\begin{array}{l}\text { Unstandardized } \\
\text { Coefficients }\end{array}$} & \multirow{2}{*}{$\begin{array}{l}\text { Standardize } \\
\text { d } \\
\text { Coefficients } \\
\text { Beta } \\
\end{array}$} & \multirow[b]{2}{*}{$\mathbf{T}$} & \multirow[b]{2}{*}{ Sig. } \\
\hline & & B & \begin{tabular}{|l|} 
Std. \\
Error
\end{tabular} & & & \\
\hline \multirow[t]{4}{*}{1} & (Constant) & 1.734 & 2.078 & & .834 & .406 \\
\hline & Kompensasi & .378 & .153 & .334 & 2.470 & .015 \\
\hline & Pelatihan Kerja & .570 & .189 & .322 & 3.016 & .003 \\
\hline & Kepuasan Kerja & .328 & .109 & .286 & 3.016 & .003 \\
\hline
\end{tabular}

a. Dependent Variable: Kinerja Karyawan Marketingn

Sumber: Output SPSS 24,0

Dari perhitungan hasil diatas didapatkan persamaan regresinya adalah sebagai berikut :

$$
\mathrm{Y}=1.734+0.378\left(\mathrm{X}_{1}\right)+0.570\left(\mathrm{X}_{2}\right)+0.328\left(\mathrm{X}_{3}\right)
$$

Berdasarkan persamaan regresi diatas, maka dapat dijelaskan sebagai berikut :

1. Nilai Konstanta 1.734 mempunyai arti bahwa apabila variabel Kompensasi $\left(\mathrm{X}_{1}\right)$,

Pelatihan Kerja $\left(\mathrm{X}_{2}\right)$ Kepuasan Kerja $\left(\mathrm{X}_{3}\right)$ dan terhadap Kinerja Karyawan Marketing (Y) sama dengan nol, maka variabel Kinerja Karyawan Marketingn akan tetap yaitu 1.734 apabila Kompensasi $\left(\mathrm{X}_{1}\right)$, Pelatihan Kerja $\left(\mathrm{X}_{2}\right)$ dan Kepuasan Kerja $\left(\mathrm{X}_{3}\right)$ terhadap Kinerja Karyawan Marketing (Y) sama dengan nol. 
2. Koefisien Regresi $X_{1}$, sebesar 0.378 mempunyai makna jika nilai variabel Kompensasi $\left(\mathrm{X}_{1}\right)$ naik satu satuan maka nilai Kinerja Karyawan Marketing (Y) akan naik sebesar 0.378 dengan asumsi variabel Kompensasi $\left(\mathrm{X}_{1}\right)$ dianggap tetap.

3. Koefisien Regresi $X_{2}$, sebesar 0.570 mempunyai makna jika nilai variabel Pelatihan Kerja $\left(\mathrm{X}_{2}\right)$ naik satu satuan maka nilai Kinerja Karyawan Marketing (Y) akan naik sebesar 0.570 dengan asumsi variabel Pelatihan Kerja $\left(\mathrm{X}_{2}\right)$ dianggap tetap.

4. Koefisien Regresi $X_{3}$, sebesar 0.328 mempunyai makna jika nilai variabel Kepuasan Kerja $\left(\mathrm{X}_{3}\right)$ naik satu satuan maka nilai Kinerja Karyawan Marketing(Y) akan naik sebesar 0.328 dengan asumsi variabel Kepuasan Kerja $\left(\mathrm{X}_{3}\right)$ dianggap tetap.

\subsection{Koefisien Determinasi (R2)}

Untuk mengetahui besarnya presentase sumbangan pengaruh variable bebas Kompensasi $\left(\mathrm{X}_{1}\right)$, Pelatihan Kerja $\left(\mathrm{X}_{2}\right)$ dan Kepuasan Kerja $\left(\mathrm{X}_{3}\right)$ terhadap variable terikat Kinerja Karyawan (Y) maka dari perhitungan computer menggunakan SPSS 24,0 didapatkan uji koefisien determinasi dapat dilihat pada tabel sebagai berikut :

Tabel 4.9

Nilai Koefisien Determinasi (R2)

\begin{tabular}{|l|c|r|r|c|}
\hline \multicolumn{5}{|c|}{ Model Summary $^{\mathbf{b}}$} \\
\hline Model & $\mathbf{R}$ & R Square & $\begin{array}{c}\text { Adjusted R } \\
\text { Square }\end{array}$ & $\begin{array}{c}\text { Std. Error of the } \\
\text { Estimate }\end{array}$ \\
\hline 1 & $\mathbf{. 8 9 5}^{\mathbf{a}}$ & $\mathbf{. 8 0 2}$ & $\mathbf{. 7 9 5}$ & $\mathbf{2 . 4 5 2 4 7}$ \\
\hline
\end{tabular}

a. Predictors: (Constant), Faktor, Kepuasan Kerja Faktor Pelatihan Kerja Kompensasi

b. Dependent Variable: Kinerja Karyawan Marketing Sumber: Output SPSS 24,0

Berdasarkan tabel 4.9 dapat diketahui nilai koefisien determinasi Adjusted $\left(\mathrm{R}^{2}\right)$ diperoleh nilai sebesar 0.802 Nilai ini mempunyai arti bahwa variabel Kompensasi $\left(\mathrm{X}_{1}\right)$, 
Pelatihan Kerja $\left(\mathrm{X}_{2}\right)$ dan Kepuasan Kerja $\left(\mathrm{X}_{3}\right)$ terhadap variabel Kinerja Karyawan Marketing memberikan sumbangan sebesar 0.802 dan $802 \%$ terhadap Kinerja Karyawan Marketing sedangkan sisahnya sebesar 0.198 atau $19.8 \%$ dipengaruhi oleh variabel lain yang tidak masuk dalam model penelitian ini.

\subsection{Uji Hipotesis}

\subsubsection{Pengujian Hipotesis Dengan Uji t}

Untuk menguji pengaruh variabel bebas secara parsial terhadap variabel terikat digunakan uji t sebagai berikut :

Tabel 4.10

Hasil Pengujian Hiotesis dengan Uji t

\begin{tabular}{|c|c|c|c|c|c|c|}
\hline \multirow{3}{*}{\multicolumn{2}{|c|}{ Model }} & \multicolumn{5}{|c|}{ Coefficients $^{\mathbf{a}}$} \\
\hline & & \multicolumn{2}{|c|}{$\begin{array}{l}\text { Unstandardized } \\
\text { Coefficients }\end{array}$} & \multirow{2}{*}{$\begin{array}{c}\begin{array}{c}\text { Standardize } \\
\text { d } \\
\text { Coefficients }\end{array} \\
\text { Beta } \\
\end{array}$} & \multirow[b]{2}{*}{$\mathbf{T}$} & \multirow[b]{2}{*}{ Sig. } \\
\hline & & B & $\begin{array}{l}\text { Std. } \\
\text { Error }\end{array}$ & & & \\
\hline \multirow[t]{4}{*}{1} & (Constant) & 1.734 & 2.078 & & .834 & .406 \\
\hline & Kompensasi & .378 & .153 & .334 & 2.470 & .015 \\
\hline & Pelatihan Kerja & .570 & .189 & .322 & 3.016 & .003 \\
\hline & Kepuasan Kerja & .328 & .109 & .286 & 3.016 & .003 \\
\hline
\end{tabular}

Sumber: Output SPSS 24.0

Melalui perhitungan yang dilakukan dengan menggunakan program SPSS, maka perbandingan antara $t_{\text {hit }}$ dengan $t_{a / 2}(n-k-1)=97-2-1=94$ (1.98552) setiap variabel sebagai berikut :

1. Kompensasi yaitu $t_{\text {hit }}>t_{\alpha / 2}(2.470>1.98552)$ dan $(\operatorname{sig}<\alpha=0,015<0,050)$, hal tersebut menyatakan bahwa adanya pengaruh Kompensasi terhadap Kinerja Karyawan Marketing pada Pada PT Agung Toyota Bengkulu . 
2. Pelatihan Kerja yaitu $t_{\text {hit }}>t_{\alpha / 2}(3.016>1.98552)$ dan $(\operatorname{sig}<\alpha=0,003<0,050)$, hal tersebut menyatakan bahwa adanya pengaruh Pelatihan Kerja terhadap Kinerja Karyawan Marketing pada Pada PT Agung Toyota Bengkulu

3. Kepuasan Kerja yaitu $t_{h i t}>t_{\alpha / 2}(3.016>1.98552)$ dan $(\operatorname{sig}<\alpha=0,003<0,050)$, hal tersebut menyatakan bahwa adanya pengaruh Kepuasan Kerja terhadap Kinerja Karyawan Marketing pada Pada PT Agung Toyota Bengkulu

\subsubsection{Pengujian Hipotesis Dengan Uji F}

Untuk menguji pengaruhh variabel bebas secara parsial terhadap variabel terikat digunakan uji F sebagai berikut :

Tabel 4.11

Hasil Pengujian Hipotesis dengan Uji F

\begin{tabular}{|c|c|c|c|c|c|c|}
\hline \multicolumn{7}{|c|}{ ANOVA $^{a}$} \\
\hline \multicolumn{2}{|c|}{ Model } & $\begin{array}{l}\text { Sum of } \\
\text { Squares }\end{array}$ & Df & Mean Square & $\mathbf{F}$ & Sig. \\
\hline \multirow[t]{3}{*}{1} & Regression & 2258.969 & 3 & 752.990 & 125.193 & $.000^{b}$ \\
\hline & Residual & 559.361 & 93 & 6.015 & & \\
\hline & Total & 2818.330 & 96 & & & \\
\hline
\end{tabular}

a. Dependent Variable: Kinerja Karyawan Marketingn

b. Predictors: (Constant), Faktor Psikologis, Kepuasan Kerja, Pelatihan Kerja Kompensasi

Sumber: Output SPSS 24,0

Berdasarkan tabel uji hipotesis dengan uji $\mathrm{F}$ diatas diperoleh $\mathrm{F}_{\text {hitung }}$ sebesar 125.193 dengan nilai $\mathrm{F}_{\text {tabel }}$ sebesar 2.1085 yaitu $(125.193>2.1085)$ dan $(\operatorname{sig} \alpha=0.000$ $<0,050$ ), maka dengan demikian dapat disimpulkan bahwa $\mathrm{H}_{4}$ diterima artinya secara simultan variabel Kompensasi $\left(\mathrm{X}_{1}\right)$, Pelatihan Kerja $\left(\mathrm{X}_{2}\right)$ Kepuasan Kerja $\left(\mathrm{X}_{3}\right)$ dan berpengaruh secara signifikan terhadap Kinerja Karyawan Marketing (Y) di Pada PT Agung Toyota Bengkulu.

\subsection{Pembahasan Hasil Penelitian}




\subsubsection{Kinerja Karyawan Marketing pada PT. Agung Toyota Bengkulu}

Hasil penelitian ini menunjukkan bahwa kinerja karyawan sudah dikatakan baik. Hal ini dapat di lihat pada karyawan marketing PT. Agung Toyota Bengkulu sudah mentaati peraturan yang telah ditetapkan oleh perusahaan dengan baik. Kinerja karyawan PT. Agung Toyota Bengkulu melakukan pekerjaan secara tepat waktu serta tugas-tugas yang dilimpahkan kepada karyawan marketing tercapainya target penjualan yang ditetapkan atau di atas target penjualan yang ditetapkan sehingga kinerja karyawan sudah mulai meningkat dibandingkan dengan sebelumnya. Kemudian dilihat dari tanggapan responden, variable Kinerja Karyawan (Y) berada pada kategori baik dengan nilai tertinggi 3.99, dan memiliki rata-rata terendah yaitu 3.49, maksudnya adalah kinerja karyawan marketing pada PT. Agung Toyota Bengkulu sudah baik. Dilihat dari 5 (Karyawan Saya datang tepat waktu) dan (Karyawan Saya mengerjakan tugas tanpa harus disuruh terlebih dahulu) artinya bahwa setiap karyawan selalu melakukan pekerjaanya sesuai dengan peraturan yang telah disepakati oleh pihak perusahaan.

\subsubsection{Kompensasi pada PT. Agung Toyota Bengkulu}

Hasil penelitian menunjukkan bahwa kompensasi yang ada diperusahaan PT. Agung Toyota Bengkulu sudah dikatakan baik, hal ini disebabkan oleh gaji dan insentif serta tunjangan yang sudah di berikan secara tepat waktu sehingga kinerja karyawan yang ada di PT. Agung Toyota Bengkulu lebih meningkat dari sebelumnya dapat di lihat dari hasil tanggapan responden, variable Kompensasi $\left(\mathrm{X}_{1}\right)$ dengan nilai tertinggi 3,86 dan nilai terendah 3,58 maksudnya adalah responden merasa sistem kompensasi di PT. Agung Toyota Bengkulu sudah baik. Dari 6 item pernyataan, item pernyataan nomor 4 (insentif yang diberikan perusahaan berdasarkan kinerja karyawan) memiliki skor tertinggi yatitu 3,86 dan item pernyataan dengan skor terendah adalah nomor 1 (Gaji yang saya terima sesuai dengan harapan) memiliki skor 3,58

\subsubsection{Pelatihan Kerja pada PT. Agung Toyota Bengkulu}


Hasil ini menunjukkan bahwa pelatihan kerja pada PT. Agung Toyota Bengkulu kategori baik. Hal ini disebabkan penyelenggaraan pelatihan di PT. Agung Toyota Bengkulu sudah rutin diselenggarakan dengan menggunakan materi pelatihan yang tepat, di dukung oleh kemampuan instruktur dalam menyampaikan materi yang sesuai dengan kebutuhan karyawan, sehingga pelatihan tersebut memberikan manfaat kepada peserta pelatihan yang diimbangi dengan kelengkapan sarana dan prasarana penunjang pelatihan sudah dikatakan baik dapat dilihat dari hasil tanggapan responden, variable Pelatihan Kerja $\left(\mathrm{X}_{2}\right)$ berada pada kategori tinggi 4.05 dan yang terendah yaitu 3.51 maksudnya adalah responden merasa materi pelatihan kerja karyawan PT. Agung Toyota Bengkulu sudah baik.

Dari 10 item pernyataan, item pernyataan nomor 1(Materi pelatihan sesuai dengan pekerjaan karyawan) memiliki skor tertinggi 4,05 dan item pernyataan nomor 4 dengan skor terendah 3,51 (Metode pelatihan yang digunakan pada saat pelatihan menarik).

\subsubsection{Kepuasan Kerja pada PT. Agung Toyota Bengkulu}

Hasil penelitian ini menyatakan bahwa kepuasan kerja yang ada di perusahaan PT. Agung Toyota Bengkulu sudah dikatakan baik. Hal ini disebabkan oleh dengan gaji yang harapan sesuai dengan pekerjaan yang dilakukan serta rekan kerja bisa di ajak bekerja sama pada PT. Agung Toyota Bengkulu sehingga kepuasan kerja sudah dikatakan baik dapat dilihat dari hasil tanggapan responden, variable Kepuasan Kerja $\left(\mathrm{X}_{3}\right)$ berada pada kategori tinggi 4.00 dan terendah yaitu 3,51 maksudnya adalah responden merasa kepuasan kerja karyawan marketing PT. Agung Toyota Bengkulu sudah baik.

\subsubsection{Pengaruh Kompensasi Terhadap Kinerja Karyawan Marketing}

Berdasarkan hasil penelitian dan pengolahan data yang dilakukan pada PT. Agung Toyota Bengkulu memlalui peneybaran kuesioner terhadap 97 orang responden yang 
telah diuji sehingga dapat diketahui pengaruh kompensasi Terhadap Kinerja Karyawan pada PT. Agung Toyota Bengkulu.

Dari analisis regresi linier berganda diperoleh persamaan $\mathrm{Y}=1.734+0.378\left(\mathrm{X}_{1}\right)$ + angka ini mempunyai makna nilai konstanta 1.734 mempunyai arti variable kompensasi $\left(\mathrm{X}_{1}\right)$ terhadap kinerja karyawan marketing $(\mathrm{Y})$ pada PT. Agung Toyota Bengkulu sama dengan nol, maka variable kinerja akan tetap yaitu, 1.734 hal ini berlaku saat dilaksanakn penelitian. Koefisien regresi variable kompensasi $\left(\mathrm{X}_{1}\right)$ sebesar 0,378 dan mempunyai makna bahwa apabila kompensasi $\left(\mathrm{X}_{1}\right)$ ditingkatkan, maka akan meningkatkan kinerja karyawan marketing (Y) pada PT. Agung Toyota Bengkulu.

Kompensasi memiliki pengaruh terhadap kinerja karyawan marketing. Hal ini terlihat uji t yang menyatakan memiliki nilai yaitu $t_{h i t}>t_{\alpha / 2}(2.470>1.98552)$ dan $(\operatorname{sig}<$ $\alpha=0,015<0,050)$, maka dari penelitian yang dilakukan dalam penelitian terdahulu menyatakan bahwa kompensasi memiliki pengaruh positif dan signifikan terhadap kinerja karyawan marketing.

Hasil penelitian ini sejalan dengan penelitian Risha Faiq Fakhri (2015) (2015) dengan judul "Pengaruh Kompensasi Dan Pelatihan Kerja Terhadap Kinerja Karyawan Dengan Kepuasan Kerja Sebagi Variable Intervening(Studi Pada PT. Audio Sumitomo Technology (AST) Indonesia)", menyatakan bahwa Kompensasi Berpengaruh Positif Terhadap Kinerja Karyawan

Hasil penelitian ini sejalan dengan penelitian Any Isvandiari (2017) dengan judul” Pengaruh Kompensasi dan Disiplin Kerja Terhadap Kinerja Karyawan Bagian Produksi PG. Meritjan Kediri” menunjukkan bahwa kompensansi $\left(\mathrm{X}_{1}\right)$ berpengaruh positif dan signifikan terhadap kinerja karyawan(Y). 
Hasil penelitian ini sejalan dengan penelitian dina kurniati ( 2018 ) dengan judul

” Pengaruh Kompensasi dan Displin Kerja Terhadap Kinerja Karyawan di PT. Marinal Indoprima Desa Kapedi Sumenep", menunjukkan bahwa Kompensasi $\left(\mathrm{X}_{1}\right)$ berpengaruh positif dan signifikan terhadap Kinerja Karyawan(Y)

Hasil penelitian ini sejalan dengan penelitian Mr. Abdul Hameed, Mphil, Muhammad Ramzan, MBA, Hafiz M. Kashif Zubair, MBA, Muhammad Arslan, MBA dengan judul " Impact Of Compensation On Employee Performance (Empirical Evidence From Banking Sector Of Pakistan)", menyatakan bahwa It is concluded from different results that compensation has positive impact on employee performance.

\subsubsection{Pengaruh Pelatihan Kerja Terhadap Kinerja Karyawan Marketing}

Berdasarkan hasil penelitian dan pengolahan data yang dilakukan pada PT. Agung Toyota Bengkulu memlalui peneybaran kuesioner terhadap 97 orang responden yang telah diuji sehingga dapat diketahui pengaruh kompensasi Terhadap Kinerja Karyawan pada PT. Agung Toyota Bengkulu.

Dari analisis regresi linier berganda diperoleh persamaan $\mathrm{Y}=1.734+0.570\left(\mathrm{X}_{2}\right)$ angka ini mempunyai makna nilai konstanta 1.734 mempunyai arti variable kompensasi $\left(\mathrm{X}_{1}\right)$ terhadap kinerja karyawan marketing $(\mathrm{Y})$ pada PT. Agung Toyota Bengkulu sama dengan nol, maka variable kinerja akan tetap yaitu, 1.734 hal ini berlaku saat dilaksanakan penelitian. Koefisien regresi variable Pelatihan Kerja $\left(\mathrm{X}_{2}\right)$ sebesar 0.570 dan mempunyai makna bahwa apabila Pelatihan Kerja $\left(\mathrm{X}_{2}\right)$ ditingkatkan, maka akan meningkatkan kinerja karyawan marketing (Y) pada PT. Agung Toyota Bengkulu.

Pelatihan Kerja memiliki pengaruh terhadap kinerja karyawan marketing. Hal ini terlihat uji t yang menyatakan memiliki nilai yaitu $t_{h i t}>t_{\alpha / 2}(3.016>1.98552)$ dan $(\operatorname{sig}<$ 
$\alpha=0,003<0,050)$, hal tersebut menyatakan bahwa adanya pengaruh Pelatihan Kerja terhadap Kinerja Karyawan Marketing pada Pada PT Agung Toyota Bengkulu

Hasil penelitian ini sejalan dengan penelitian Erma Safitri (2013) dengan judul” Pengaruh Pelatihan Dan Displin Kerja Terhadap Kinerja Karyawan Pada PT. Angkasa Pura 1 (Persero) Cabang Bandar Udara Internasional Juanda-Surabaya" Menyatakan Bahwa Pelatihan kerja berpengaruh postif terhadap kinerja karyawan

Hasil penelitian ini sejalan dengan penelitian Leonando Agusta dan Eddy Madiono Sutanto (2013) dengan judul” Pengaruh Pelatihan Dan Motivasi Kerja Terhadap Kinerja Karyawan Cv Haragon Surabaya", Pelatihan $\left(\mathrm{X}_{1}\right)$ berpengaruh positif dan signifikan terhadap kinerja karyawan (Y)

Hasil penelitian ini sejalan dengan penelitian Lia Riantika Tanujaya (2015) dengan judul" Pengaruh Pelatihan Kerja dan Motivasi Kerja pada Kinerja Karyawan Departemen Produksi PT Cornet Crown", menyatakan bahwa pelatihan kerja berpengaruh positif dan signifikan terhadap kinerja karyawan

Hasil penelitian ini sejalan dengan penelitian Ilham Thaief Aris Baharuddin, Priyono \& Mohamad Syafi'I Idrus (2015)dengan judul” Effect Of Training, Compensation And Work Discipline Against Employee Job Performance”, menyatakan bahwa The training simultaneously and partially have significant effects toward the employee work performance

\subsubsection{Pengaruh Kepuasan Kerja Terhadap Kinerja Karyawan Marketing}

Berdasarkan hasil penelitian dan pengolahan data yang dilakukan pada PT. Agung Toyota Bengkulu memlalui peneybaran kuesioner terhadap 97 orang responden yang telah diuji sehingga dapat diketahui pengaruh kompensasi Terhadap Kinerja Karyawan pada PT. Agung Toyota Bengkulu. 
Dari analisis regresi linier berganda diperoleh persamaan $\mathrm{Y}=1.734+0.328$ angka ini mempunyai makna nilai konstanta 1.734 mempunyai arti variable kompensasi $\left(\mathrm{X}_{1}\right)$ terhadap kinerja karyawan marketing (Y) pada PT. Agung Toyota Bengkulu sama dengan nol, maka variable kinerja akan tetap yaitu, 1.734 hal ini berlaku saat dilaksanakn penelitian. Koefisien regresi variable Kepuasan Kerja $\left(\mathrm{X}_{3}\right)$ sebesar 0.328 dan mempunyai makna bahwa apabila Kepuasan Kerja $\left(\mathrm{X}_{3}\right)$ ditingkatkan, maka akan meningkatkan kinerja karyawan marketing (Y) pada PT. Agung Toyota Bengkulu.

Kepuasan Kerja memiliki pengaruh terhadap kinerja karyawan marketing. Hal ini terlihat uji $t$ yang menyatakan memiliki nilai Kepuasan Kerja yaitu $t_{h i t}>t_{\alpha / 2}(3.016>$ 1.98552) dan ( $\operatorname{sig}<\alpha=0,003<0,050)$, hal tersebut menyatakan bahwa adanya pengaruh Kepuasan Kerja terhadap Kinerja Karyawan Marketing pada Pada PT Agung Toyota Bengkulu

Hasil penelitian ini sejalan dengan penelitian Iwan Kurnia Wijaya (2018) dengan judul" Pengaruh Kepuasan Kerja Terhadap Kinerja Karyawan Cv Bukit Sanomas" menyatakan bahwa kepuasan kerja Sanomas memiliki pengaruh terhadap kinerja karyawan.

Hasil penelitian ini sejalan dengan penelitian Ayu Desi Indrawati (2013) dengan judul" Pengaruh kepuasan kerja terhadap kinerja karyawan dan kepuasan kerja pelanggan pada rumah sakit swasta di kota denpasar", menyatakn bahwa Kepuasan kerja berpengaruh signifikan yang positif terhadap kinerja karyawan

Hasil penelitian ini sejalan dengan penelitian Garry Surya Changgriawan (2017) dengan judul" Pengaruh Kepuasan Kerja Dan Motivasi Kerja Terhadap Kinerja Kinerja Karyawan Di One Way Production” Menunjukkan Bahwa Kepuasan Kerja Berpengaruh Terhadap Kinerja Karyawan 
Hasil penelitian ini sejalan dengan penelitian Adigun A. O. (Ph.D), Oyekunie I. A and Onifade T.A (2017)dengan judul" Influence Of Job Satisfaction On Employees Performance In Mtn Nigeria”, menyatakan bahwa job satisfactions have an influence on employees' performance

\subsubsection{Pengaruh Kompensasi, Pelatihan Kerja Dan Kepuasan Kerja Terhadap Kinerja Karyawan Marketing}

Berdasarkan hasil penelitian dan pengolahan data yang dilakukan pada PT. Agung Toyota Bengkulu memlalui peneybaran kuesioner terhadap 97 orang responden yang telah diuji sehingga dapat diketahui pengaruh kompensasi Terhadap Kinerja Karyawan pada PT. Agung Toyota Bengkulu.

Kompensasi $\left(\mathrm{X}_{1}\right)$, Pelatihan Kerja $\left(\mathrm{X}_{2}\right)$ dan Kepuasan Kerja $\left(\mathrm{X}_{3}\right)$ memiliki pengaruh terhadap kinerja karyawan marketing (Y), hal ini terlihat pada uji $\mathrm{F}$ yang menyatakan nilai $\mathrm{F}_{\text {tabel }}$ sebesar 2.1085 yaitu $(125.193>2.1085)$ dan $(\operatorname{sig} \alpha=0.000<$ 0,050), maka dengan demikian dapat disimpulkan bahwa $\mathrm{H}_{4}$ diterima artinya secara simultan variabel Kompensasi $\left(\mathrm{X}_{1}\right)$, Pelatihan Kerja $\left(\mathrm{X}_{2}\right)$ Kepuasan Kerja $\left(\mathrm{X}_{3}\right)$ dan berpengaruh secara signifikan terhadap Kinerja Karyawan Marketing (Y) di Pada PT Agung Toyota Bengkulu

Hasil penelitian ini sejalan dengan penelitian Risha Faiq Fakhri (2015) (2015) dengan judul "Pengaruh Kompensasi Dan Pelatihan Kerja Terhadap Kinerja Karyawan Dengan Kepuasan Kerja Sebagi Variable Intervening(Studi Pada PT. Audio Sumitomo Technology (AST) Indonesia)", menyatakan bahwa Kompensasi Pelatihan Kerja Berpengaruh Positif Terhadap Kinerja Karyawan 


\section{BAB V \\ KESIMPULAN DAN SARAN}

\subsection{Kesimpulan}

Berdasarkan hasil penelitian yang telah dilakukan tentang pengaruh Kompensasi , Pelatihan Kerja , Kepuasan Kerja dan Terhadap Kinerja Karyawan Marketing (Y) Pada PT Agung Toyota Bengkulu, dapat disimpulkan sebagai berikut :

1. Kompensasi berpengaruh signifikan terhadap Kinerja Karyawan Marketing pada Pada PT Agung Toyota Bengkulu.

2. Pelatihan Kerja berpengaruh signifikan terhadap Kinerja Karyawan Marketing pada Pada PT Agung Toyota Bengkulu.

3. Kepuasan Kerja berpengaruh signifikan terhadap Kinerja Karyawan Marketing pada Pada PT Agung Toyota Bengkulu..

4. Kompensasi $\left(\mathrm{X}_{1}\right)$, Pelatihan Kerja $\left(\mathrm{X}_{2}\right)$, dan Kepuasan Kerja $\left(\mathrm{X}_{3}\right)$ memilki berpengaruh terhadap Kinerja Karyawan Marketing (Y).

\subsection{Saran}

Berdasarkan hasil penelitian, pembahasan dan kesimpulan yang diperoleh, maka saran yang dapat diberikan sebagai berikut :

1. Hasil penelitian menunjukan adanya pengaruh antara variabel Kompensasi $\left(\mathrm{X}_{1}\right)$, Pelatihan Kerja $\left(\mathrm{X}_{2}\right)$, dan Kepuasan Kerja $\left(\mathrm{X}_{3}\right)$ signifikan terhadap Kinerja Karyawan Marketingn (Y) Pada Pada PT Agung Toyota Bengkulu, variabel Kompensasi memiliki rata-rata terendah yaitu 3.58. Disarankan bagi pihak perusahaan lebih meningkatkan dan memperhatikan gaji karyawan agar dapat meningkatkan Kinerja Karyawan Marketing pada Pada PT Agung Toyota Bengkulu 
2. Hasil penelitian terlihat bahwa pada variabel pelatihan kerja memiliki tanggapan responden yang terendah yaitu 3,51. Disarankan metode pelatihan lebih menarik dari yang sebelumnya agar lebih meningkatkan semangat dalam proses pelatihan.

3. Hasil penelitian terlihat bahwa pada variabel Kepuasan Kerja memiliki tanggapan responden yang terendah yaitu 3,51. Disarankan bagi perusahaan lebih tepat menempatkan karyawan diposisi yang lebih tepat.

4. Disarankan bagi peneliti selanjutnya khususnya penelitian yang sama perlu dipertimbangkan untuk Kompensasi $\left(\mathrm{X}_{1}\right)$, Pelatihan Kerja $\left(\mathrm{X}_{2}\right)$, dan Kepuasan Kerja $\left(\mathrm{X}_{3}\right)$ terhadap Kinerja Karyawan Marketing (Y) serta diluar variable terhadap Kinerja Karyawan Marketingn serta dapat mengembangkan jumlah respondennya sehingga akan menghasilkan penelitian yang lebih baik dan sesuai dengan peningkatan kualitas penelitian selanjutnya.

\section{DAFTAR PUSTAKA}

Adigun A. O. (Ph.D), Oyekunie I. A and Onifade T.A 2017. Influence Of Job Satisfaction On Employees Performance In Mtn Nigeria. Global journal of human resource management vol. no. 5, pp. 54060, june 2017

Akbar, P. dan Usman, H. (2009). Metode penelitian social. Jakarta: Bumi Aksara

Anjani, R. (2019). Tata Kelola Adminitrasi Keuangan, Dan Pembangunan Desa Tepi Laut Kabupaten Bengkulu Utara. Jurnal Pengabdian Masyarakat Bumi Raflesia, 2 (2).

Any Isvandiari (2017). Pengaruh Kompensasi dan Disiplin Kerja Terhadap Kinerja Karyawan Bagian Produksi PG. Meritjan Kediri. Jurnal JIBEKA, Volume 11 No. 1 Agustus 2017

Asmawi, M. (2017). The effect of compensation, empowerment, and job satisfaction on employee loyalty. International Journal of Scientific Research and Management, 5(12), 7590-7599.

Atmajawati, Yayah. 2007, Pengaruh Variable Kompensasi, Motivasi Dan Kepuasan Kerja Terhadap Keluar Masuk Pegawai (Labour Turnover) Pada PT. Jsaraharja Putera Surabaya. Garuda, referensi Ilmiah Indonesia,2007 
Ayu Desi Indrawati (2013). Pengaruh Kepuasan Kerja Terhadap Kinerja Karyawan Dan Kepuasan Kerja Pelanggan Pada Rumah Sakit Swasta Di Kota Denpasar. Jurnal Manajemen, Strategi Bisnis, Dan Kewirausahaan Vol. 7. No.2. Agustus 2013

Badriyah, M. (2015). Manajemen Sumber Daya Manusia, Cetakan 1. Bandung: CV Pustaka Setia.

Dina kurniati ( 2018 ). Pengaruh Kompensansi dan Displin Kerja Terhadap Kinerja Karyawandi PT. Marinal Indoprima Desa Kapedi Sumenep. Jurnal Pemikiran \& Penelitian Ekonomi ISSN : 2339-2185

Dessler, Gary (2007) Manajemen Sumber Daya Manusia, Jilid II, Edisi ke 10. Jakarta: PT. Indeks

Erma Safitri (2013). Pengaruh Pelatihan Dan Displin Kerja Terhadap Kinerja Karyawan Pada Pt. Angkasa Pura 1 (Persero) Cabang Bandar Udara Internasional JuandaSurabaya. Jurnal Ilmiah Manajemen. Volume 1 Nomor 4 Juli 2013

Gary, Dessler 2015, Manajemen Sumber Daya Manusia, Jakarta: selemba empat.

Garry Surya Changgriawan (2017). Pengaruh Kepuasan Kerja Dan Motivasi Kerja Terhadap Kinerja Kinerja Karyawan Di One Way Production. Agora. Vol. 5. No. 3. (2017)

Ghozali, Imam. 2011. "Aplikasi Analisis Multivariate Dengan Program SPSS”.

Semarang: Badan Penerbit Universitas Diponegoro.

Ghozali (2016). Aplikasi Analisis Multivariete dengan program IBM SPSS 23. Edisi Ke 8.

Hamalik. (2007). Manajemen Pelatihan Ketenagakerjaan Pendekatan. Jakarta : Bumi. Aksara.

Handoko, T.. Hani. 2001. Manajemen Personalia Dan Sumber Daya Manusia. Edisi ke 14. Yogyakarta: BPFEE

Handoko T. Hani, 2010, Manajemen Sumber Daya Manusia, BPFE, Yogyakarta.

Hasibuan. Malayu S.P (2009), Manajemen Sumber Daya Manusia Erlangga, Jakarta.

Hartatik, Puji Indah. 2014. Buku Praktis Mengembangkan SDM. Jogjakarta: Laksana.

Ilham Thaief Aris Baharuddin, Priyono \& Mohamad Syafi'I Idrus (2015). Effect Of Training, Compensation And Work Discipline Against Employee Job Performance. Review of European studies, vol 7. No. 11. (http;//eprints.binadarma.ac.id cdiakses pada tanggal 15 oktober 2017)

Iwan Wijaya (2018). Pengaruh Kepuasan Kerja Terhadap Kinerja Karyawan Cv Bukit Sanomas. Agora. Vol. 6. No. 2 (2018) 
Kaswa. 2011. Pelatihan Dan Pengembangan Untuk Meningkatkan Kinerja SDM. Bandung: Alfabeta.

Leonando Agusta dan EddyMadiono Sutanto (2013). Pengaruh Pelatihan Dan Motivasi Kerja Terhadap Kinerja Karyawan Cv Haragon Surabaya. Agora. Vol. 1. No. 3. (2013)

Lia Riantika Tanujaya (2015). Pengaruh Pelatihan Kerja dan Motivasi Kerja pada Kinerja Karyawan Departemen Produksi PT Cornet Crown. Agora. Vol. 3. No.1. (2015)

Luthans, F. (2007). Organizational Behavior (11 $1^{\text {th }}$ ed). Singapore: McGraw Hill Company.

Malthis. 2006. Manajemen sumber daya manusia. Salemba Empat. Jakarta.

Mangkunegara, A.P (2013). Manajemen sumber daya manusia. Bandung: $\quad$ PT. Remaja Rosdakarya

Mangkunegara,A.A Anwar Prabu. 2010. Evaluasi Kinerja SDM. Bandung: PT. Revika Aditama.

Mangkunegara, A.P. 2008. Perencanaan Dan Pengembangan Sumber Daya Manusia. Bandung: Refika Aditama.

M. abdul kholil, Marzolina, Taufiqurrahma. (2014). Pengaruh Displin Dan Lingkungan Kerja Terhadap Kinerja Karyawan Pabrik Pada Pt. Inti Karya Plasma Perkasa Tapung. Jom FEKON Vol. 1 No. 2 Oktober 2014

Mangkunegara, A.P. 2008. Perencanaan Dan Pengembangan Sumber Daya Manusia. Bandung: Refika Aditama

Mr. Abdul Hameed, Mphil, Muhammad Ramzan, MBA, Hafiz M. Kashif Zubair, MBA, Muhammad Arslan, MBA .2014. Impact Of Compensation On Employee Performance (Empirical Evidence From Banking Sector Of Pakistan). Internasional journal of business and social science. Vol. 5. No. 2. February 2014

Onsardi, O. (2018). Loyalitas Karyawan pada Universitas Swasta di Kota Bengkulu. COSTING: Journal of Economic, Bussines and Accounting, 2(1), 1-13.

Onsardi, O. (2019). Effect Of Empowerment On Employees Performance (No. v7g9t). Center for Open Science.

Rivai, V. (2004). Manajemen Sumber Daya Manusia Untuk Perusahaan: Dari Teori Ke Praktek. Jakarta: Rajawali Pers. 
Rivai V. \& Sagala E.J (2013) Manajemen Sumber Daya Manusia untuk perusahaan. Jakarta: PT. Raja Grafindo Persada.

Robbins, S.P (2006). Perilaku Organisasi. PT. Indeks, Kelompok Gramedia, Jakarta.

Robbins, Coulter. 2010. Manajemen. Jakarta:Erlangga

Risha Faiq Fakhri (2015). Pengaruh Kompensasi Dan Pelatihan Kerja Terhadap Kinerja Karyawan Dengan Kepuasan Kerja Sebagi Variable Intervening(Studi Pada PT. Audio Sumitomo Technology (AST) Indonesia). Volume 4, Nomor 4, Tahun 2015, Halaman 1-15

Sedarmayanti. (2011). Metodologi penelitian. Bandung: Munandar maju.

Sjafri. (2009). Bisnis, Manajemen, dan Sumber Daya Manusia. Bogor : IPB Press.

Torang, S. (2013) Organisasi dan manajemen; perilaku, struktur, budaya \& perubahan organisasi. Bandung: penerbit Alfabeta.

Selvy Mutiara, Syahrum Agung Dan Undang Suryana, 2016. Pengaruh Displin Kerja dan Stress Kerja Terhadap Kinerja Karyawan Pada Pt. Kereta Api Indonesia (pesero) Daerah Operasi 1 Jakarta. Jurnal Iilmiah Innovator, Edisi September.

Sedarmayati (2010) Manajemen Sumber Daya Manusia. Reformasi Birokrasi \& Manajemen Pegawai Negeri Sipil. Bandung: PT. Refika Aditama

Sultana, Afshan., Irum, Sobia., Ahmed, Kamran., dan Mehmood, Nasir. 2012.'Impact of training on employee performance : A study of telecommunication sector in pakistan”. Interdisciplinary Journal Of Contemporary Reseacrh In business 4 (6): 646-661

Sinambela, Lijan Poltak. 2012. Kinerja Pegawai. Yogyakarta: Graha Ilmu.

Sugiyono, (2012). Metode Penelitian Kuantitatif Kualitatif Dan R\&D. Bandung: Alfabeta.

Sugiyono. 2010. Metode Penelitian Pendidikan Pendekatan Kuantitatif,Kualitatif, dan $R \& B$. Bandung : Alfabeta

Sofiandi, H. (2008). Manajemen Sumber Daya Manusia. Jakarta: Penerbit Graha.

Sutrisno, E. (2009). Manajemen Sumber Daya Manusia. Jakarta: Kencana

Sutrisno, e., \& rachmady, r. (2011). Preliminary observations of yhe gy of the critically endangered white-shouldered iblis pseudibis davisoni in east Kalimantan. Kukila, 14, 32-35. View in (google scholar) 
Titisari, Purnami. 2014. Peranan Organizational Citizenship Behavior (OCB): Dalam Meningkatkan Kinerja Karyawan. Jakarta: Mitra Wacana Media.

Wibowo (2014). Manajemen Kinerja. Edi Keempat. Jakrta : Rajawali Pers.

Wibowo (2014). Perilaku Dalam Organisasi, Jakarta : Rajawali Pers.

Wirawan (2013). Kepimpinan: Teori Psikolog, Perilaku Organisasi, Aplikasi \& Penelitian. Jakarta: PT. Raja Grafindo Persada.

Yamoah, Emmanuel Erastus, 2013. Reward Systems And Teacher's Performance: Evidence From Ghana. Canadion Social Science. 